\title{
Land Use Incentives for Real Estate Developers in Social Rental Housing Projects (Case study: Degla Gardens Project-October Gardens-Six October City)
}

\author{
Abeer Ahmed Mohamed Abd-Elkawy \\ Department of urban planning, Faculty of Urban and Regional Planning \\ Cairo University, Giza, Egypt \\ Tel: 002-010-0697-3883Ｅ-mail:abeer_planner@yahoo.com
}

Received: December 18, 2019 Accepted: January 6, 2020 Published: January 21, 2020

doi:10.5296/emsd.v9i1.16247ＵRL: https://doi.org/10.5296/emsd.v9i1.16247

\begin{abstract}
Social rental housing projects have emerged since 2016 to cover the housing demand of low-income groups, but these projects need high cost that beyond the financial capacity of some governments. Therefore, the World Bank reports in 2014 and 2018 pointed to the importance of including the private sector in low-income housing projects as a real estate developer instead of the state. The contribution of private sector and his successful experience in this field help in reducing the government spending towards these projects and achieving high quality in their implementation. For these reasons, many countries at international level involved the private sector in construction of social housing units in exchange for a set of incentives, which vary widely from one country to another. These incentives are classified into two main groups, the first one is financial and administrative incentives such as providing free land or selling it at low price, besides taxes and financing facilities as applied in Brazil, China, Singapore and Thailand. The second group is new incentives which called Land use incentives such as land use kind, percentage of land exploitation, proposed density and land use regulation in the housing project as applied in the United States, Japan and France because the previous financing incentives are not enough to achieve an appropriate profit for investors.

At the local level, the private sector participated in many low-income housing projects such as Youth Housing, National Housing and social housing projects during the period from 1996 until now. In which the Egyptian government provided him some incentives like low price land, payment facilities, tax cuts and allocation part of land for his investment projects in exchange for building number of housing units with an area of $\left(63 \mathrm{~m}^{2}\right)$ for low-income
\end{abstract}


groups. On the other hand, real estate companies retreated from participation in these projects because the incentives are unsatisfactory to them, which made the state played again the role of real estate developer to fill the gap in housing demand by using insufficient government budget.

As a result of that, the Egyptian government is trying nowadays to re-engage the private sector again in future social housing projects by studying all submitted proposals from private sector in 2016, the World Bank in 2018 and the views of some institutions such as ministry of investment, ministry of housing and the Social Housing Fund in 2019 around the new incentives, especially after the state decided to withdraw from real estate development and leave it to the private sector by the year 2020. Hence, this paper tries to introduce the new incentives for private sector to participate again in social housing projects. The formulation of these incentives comes from revision the international experiences and reports as well as evaluating the applying of old incentives in one case study of participation housing projects (Degla Gardens project to find an integrated vision for suitable incentives in Egyptian reality that achieve the goals of all development parties ( the government-private sector-population).

Keywords:Land use incentives, Real estate developers, Social rental housing projects, Public private partnership (PPP), Degla Gardens project.

\section{Introduction}

The demand of social rental housing increases nowadays in many countries, especially in developing countries due to high price of housing units with tamlek system, which exceeds the purchasing power of low-income groups. This type of housing appeared in the early second half of the twentieth century through the state to provide cheap housing units (government housing), but with the lack of adequate government funding (Ademiluyi and Raji, 2008), there is a need to seek new housing policies based on alternative sources of funding and innovative planning and design methods. The participation of private sector is one of these policies that delivers affordable housing for middle and low-income families, with high efficient and less time through government incentives in legislative, regulatory and administrative frameworks (Zhang, 2005; Abdul-Aziz, and Jahn, 2011)

Some countries like Brazil, China and Germany applied number of financial and administrative incentives in the partnership housing projects, to benefit from the expertise of private sector and accelerate in housing development (World Bank, 2014b). Financial incentives are used usually in the case of existence adequate government funding for these projects, where the state provides loans, exemptions and concessions for real estate companies to complete their projects in short time. However, these incentives are often insufficient due to the high costs of low-income housing projects compared to their returns, which make a limited number of companies have a willingness to invest in this type of housing projects (Horowitz, 1996).

Therefore, some countries like the United States, Japan, France, China and Korea have adopted new incentives to attract more in the low-income housing sector. Theses incentives depend mainly on how to exploit project land in better way by controlling its land use, 
density and diversity, to cover costs and achieve profits for each of the state, population and investors without increasing the financial burden on the government or reducing the efficiency of residential areas (MDNR, 2001; ElBoghdady, 2011; World Bank, 2014b).

At the local level, the Egyptian government played the main role in low-income rental housing market since the 1950 s by building government rental housing within the period from 1952 to 1973 . After the decline in government financial resources during the war period, the private sector contributed to real estate development, especially for the middle-income groups. In addition, his participation extended to low income housing project from the year of 1995, when many housing projects started in new cities such as youth housing project in 1995, National Housing Project (Iskan Mubarak) in 2006 and social housing project in 2014. In these housing projects, the Egyptian government provided incentives for real estate companies like allocation cheap land, administrative support and exemptions from fees and taxes. These incentives have been applied similarly in all kinds of social housing projects, whether subsidized or unsupported and in different utilization systems (ownership or rent), which made many companies did not achieve the expected profitability in some projects (USAID, 2007; Chaarawi et al.,2016).

For these reasons, the state is trying now to introduce meaningful incentives to real estate companies that use optimal land use and less government spending in return for the highest possible returns for all partnership parties. Thus, the importance of this paper lies in formation additional new incentives for private sector to participate in future social rental housing projects. Through an analytical approach for good government incentives in international reports and countries experiences, in addition to the practical approach for one case study of PPP low income housing projects in new Egyptian cities, to identify the main challenges of current applied incentives and their contribution in attracting private sector in this type of housing projects.

\section{Definition of Land Use Incentives}

The term of incentives refers to the tools that can be used to motivate someone to do specific tasks, and it is widely used in the field of companies and industrial activities, to encourage businesspersons and workers for producing an efficient product at the lowest cost and the least time.

Recently, this term has expanded to include the partnership between the state and the private sector, in which the state offers grants and financial contribution, concessions, services, permits, administrative and organizational facilities...to enable investors to invest in one of economic sectors (Zhang, 2005). The developed countries use three types of investment incentives, the first type is financial incentives, such as government financing, grants and interest-free loans or subsidized loans to cover part of the project capital and production costs. The second type is tax incentives such as reduction or exemption from taxes and fees. While the last type is administrative incentives which are related to facilities in the procedures to reduce the required time for the project whenever possible (Horowitz, 1996; Altus Group, 2013). 


\section{Macrothink}

The implementation of incentives began in the projects of roads and utilities development to support their high cost, then emerged in other economic projects to achieve more economic growth and returns at the international and local level. Some countries made attention to the importance of using incentives for private sector in housing development since seventies, where the governments have targeted for providing more units of low-income housing by alternative funding sources such as real estate companies, investors or banks because limited government funding for these projects (Ademiluyi and Raji, 2008).

The definitions of incentives in the field of housing projects have varied according to their types and the state goals from the partnership process with the private sector. Financial incentives are the first provided incentives to the private sector during the 1960s and 1970s, which refer to the financial government contribution in partnership housing projects through direct financing, reduction in land price, supported loans by low long-term or short-term interest, exemptions from tax and duty and financial grants that are not refunded again. The government uses one or all these incentives according to the characteristics of each housing project (its type, purpose, costs and its returnsto the society). Since the 1980s and 1990s, the administrative, institutional and regulatory incentives have emerged due to the importance of time for many investors. These incentives are defined as the facilitation in procedures of registration and licensing during all project stages, by legislative and regulatory frameworks in each government institutions to protect the investment process from any obstacles (Scherlowski, 1999; Perera, 2005; Zhang, 2005; World Bank, 2014b).

However, with the decrease in government funding and insufficient administrative incentives, there is a need for new incentives by exploiting the available possibilities of land at the lowest cost. These incentives are called (land use incentives) which appeared since the late of nineties in the USA (New York City), and concerned with achieving optimal land use within housing projects to meet the population needs, the objectives of the state and investor profitability in a balanced manner. Land use incentives include some sub-incentives, such as land use kind, land use ratio, land use density, mix land use, time of land use development and land use regulations. These incentives which are appropriate for developing countries due to the state ownership for the land and its control over land use through the regulatory and legal frameworks. The following figure no (1) illustrates the evolution of incentives definition, especially land use incentives in the field of housing projects (Perera, 2005; Sengupta, 2006; Kofner, 2009; ElBoghdady, 2011; Kolsteren, 2012; City of Vancouver; 2012; Lewchuk, 2013; City of Vancouver, 2014). 


\section{Macrothink}

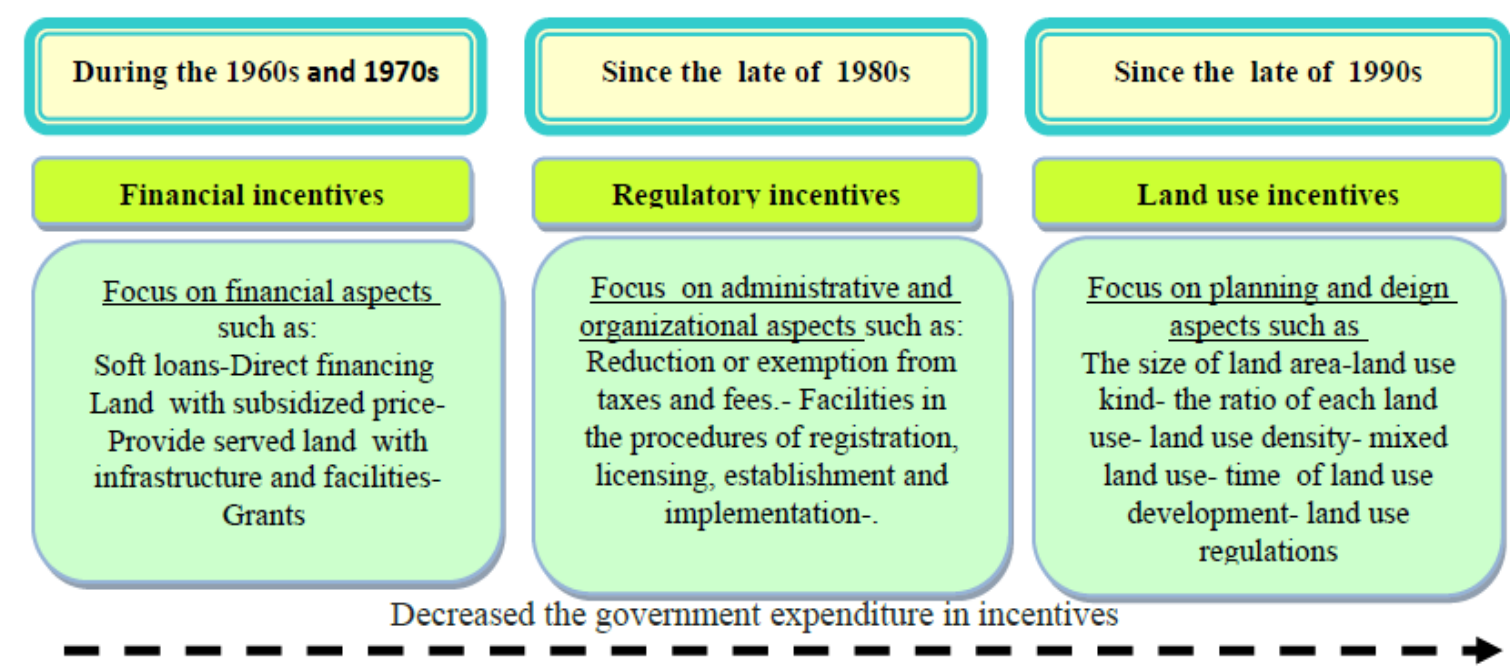

Figure 1. The evolution of incentives definition, especially land use incentives in housing projects

(Source: Author)

\section{Advantages and Disadvantages of Incentives in Social Rental Housing Projects}

The using of incentives in low-income housing projects is characterized by a set of advantages and disadvantages, which differ from project to other according to the types of incentives and the participating parties in each housing project. In which the participating parties are the state that provides the incentives, private sector who obtains the incentives or the beneficiaries from population (Buttiiner, 2006; Cartlidge, 2006) as shown in the following tables (1), in addition to figure no (2) which shows the importance of land use incentives in low income housing projects.

\begin{tabular}{|c|c|c|}
\hline $\begin{array}{c}\text { Reduce the housing } \\
\text { unit price }\end{array}$ & $\begin{array}{c}\text { Diversity and integration } \\
\text { in land use }\end{array}$ & $\begin{array}{c}\text { Build more housing } \\
\text { units }\end{array}$ \\
\hline $\begin{array}{c}\text { Better use of land } \\
\text { value }\end{array}$ & $\begin{array}{l}\text { Importance of land use } \\
\text { incentives in low-income } \\
\text { housing projects. }\end{array}$ & $\begin{array}{l}\text { Less government } \\
\text { spending }\end{array}$ \\
\hline $\begin{array}{l}\text { sustainability of } \\
\text { residential areas }\end{array}$ & $\begin{array}{c}\text { Flexibility and diversity in } \\
\text { design }\end{array}$ & $\begin{array}{l}\text { High profit for private } \\
\text { sector }\end{array}$ \\
\hline
\end{tabular}

Figure 2. The importance of using land use incentives in low income housing projects

(Source: Author) 


\section{Macrothink}

Table 1. The main Advantages and disadvantages of each incentive for the state, private sector and population in low housing project:

\begin{tabular}{|c|c|c|c|c|}
\hline \multirow{2}{*}{\multicolumn{2}{|c|}{$\begin{array}{c}\text { Types of } \\
\text { incentives }\end{array}$}} & \multicolumn{3}{|c|}{ The participating parties } \\
\hline & & The state & The private sector & The population \\
\hline \multirow{2}{*}{$\begin{array}{l}\text { Financial } \\
\text { incentives }\end{array}$} & 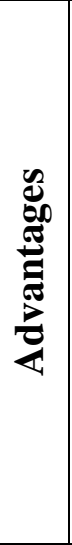 & $\begin{array}{l}\text {-Benefit from the private sector } \\
\text { expertise. } \\
\text { - Diversity in designs. } \\
\text {-Achieve less time for project. } \\
\text { - Increase real estate activity. } \\
\text {-Employment of labor. } \\
\text { - Provide housing demand. }\end{array}$ & $\begin{array}{l}\text {-Existence the financial } \\
\text { liquidity for the project. } \\
\text {-Obtain soft loans. } \\
\text {-Get the land at low price. } \\
\text {-Reduce project execution } \\
\text { time. } \\
\text {-Raise the efficiency of } \\
\text { residential areas. } \\
\text {-Achieve an appropriate profit } \\
\text { margin. }\end{array}$ & $\begin{array}{l}\text {-Cover part of low- income } \\
\text { housing demand. } \\
\text {-Increase the supply of } \\
\text { housing units compared to } \\
\text { demand in the case of high } \\
\text { funding. } \\
\text {-High quality of } \\
\text { implementation with high } \\
\text { funding. }\end{array}$ \\
\hline & 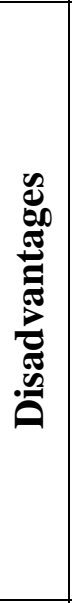 & $\begin{array}{l}\text {-Financial burden on the state. } \\
\text {-Influence on the development } \\
\text { of other economic sectors. } \\
\text {-Take a long time for housing } \\
\text { project with funding problems. } \\
\text {-The availability of limited } \\
\text { number of housing units } \\
\text { according to the size of } \\
\text { funding. }\end{array}$ & $\begin{array}{l}\text {-Profit margin correlates with } \\
\text { funding size. } \\
\text {-The state controls the } \\
\text { elements of the project } \\
\text { according to its objectives. } \\
\text {-The time and characteristics } \\
\text { of the project depend on the } \\
\text { size of government funding. } \\
\text {-Facing constraints due to } \\
\text { poor funding in developing } \\
\text { countries. }\end{array}$ & $\begin{array}{l}\text {-High price of housing unit } \\
\text { compared to low incomes of } \\
\text { population. } \\
\text {-Implement fewer number of } \\
\text { housing units as a results of } \\
\text { poor funding. } \\
\text {-Lack of services and } \\
\text { facilities in the project } \\
\text { because their high cost. }\end{array}$ \\
\hline \multirow[b]{2}{*}{$\begin{array}{l}\text { Regulatory } \\
\text { incentives }\end{array}$} & 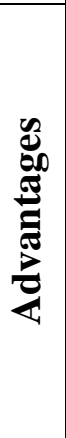 & $\begin{array}{l}\text {-Benefit from private sector } \\
\text { expertise and his financial } \\
\text { liquidity. } \\
\text {-Reduce the government } \\
\text { spending on housing projects. } \\
\text {-Diversity of designs. } \\
\text {-Accelerate the establishment } \\
\text { of housing units in less time. }\end{array}$ & $\begin{array}{l}\text {-Facilitate the required } \\
\text { procedures for the project. } \\
\text { - Exemptions or reductions } \\
\text { from taxes and fees. } \\
\text {-Reduce the required time to } \\
\text { implement the project. } \\
\text {-Achieve profit margin in less } \\
\text { time. }\end{array}$ & $\begin{array}{l}\text {-Cover their needs from } \\
\text { housing units in less time. } \\
\text {-Efficient in implementation } \\
\text { the residential areas. } \\
\text {-Facilitate the procedures for } \\
\text { obtaining the housing unit. }\end{array}$ \\
\hline & 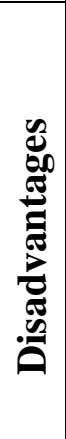 & $\begin{array}{l}\text {-Need for new laws and } \\
\text { regulations. } \\
\text {-Need for continuous } \\
\text { monitoring of implementation } \\
\text { the administrative incentives. } \\
\text {-The state bears part of the } \\
\text { taxes and fees to facilitate the } \\
\text { housing projects. }\end{array}$ & $\begin{array}{l}\text {-Regulatory incentives are not } \\
\text { enough for private sector } \\
\text { participation in housing } \\
\text { projects. } \\
\text {-The profit ratio depends } \\
\text { more on the financial support } \\
\text { than the organizational } \\
\text { support. }\end{array}$ & $\begin{array}{l}\text {-High price of housing unit } \\
\text { compared to low incomes of } \\
\text { population. } \\
\text {-Implement fewer units as a } \\
\text { results of low funding. } \\
\text {-the residential areas are } \\
\text { affected by inefficient } \\
\text { controls. }\end{array}$ \\
\hline
\end{tabular}




\begin{tabular}{|c|c|c|c|c|}
\hline \multirow[t]{2}{*}{$\begin{array}{l}\text { Land use } \\
\text { incentives }\end{array}$} & 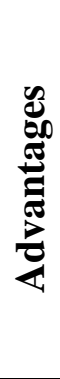 & $\begin{array}{l}\text {-Optimization the using of other } \\
\text { state resources. } \\
\text {-Reduce government fiscal } \\
\text { spending. } \\
\text {-Provide a larger supply of } \\
\text { housing units. }\end{array}$ & $\begin{array}{l}\text {-Optimization the using of } \\
\text { project area. } \\
\text {-Diversity in land use. } \\
\text {-Building more housing units. } \\
\text {-Achieve higher profit margin } \\
\text { and cover the high costs. }\end{array}$ & $\begin{array}{l}\text { - Building more housing units } \\
\text { for low-income groups. } \\
\text {-Availability of services and } \\
\text { employment opportunities in } \\
\text { the residential area. } \\
\text { - The lowest price per unit. } \\
\text {-Flexibility in designs. }\end{array}$ \\
\hline & 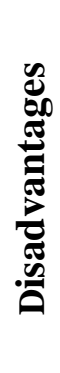 & $\begin{array}{l}\text {-Need for new land use } \\
\text { regulations. } \\
\text {-Need to achieve the balance } \\
\text { between the goals of the state, } \\
\text { the private sector and the } \\
\text { population. }\end{array}$ & $\begin{array}{l}\text {-Need for financial and } \\
\text { institutional support besides } \\
\text { this kind of incentive. } \\
\text {-The ratio of profitability } \\
\text { correlates with kind of land } \\
\text { use incentives and facilities. }\end{array}$ & $\begin{array}{l}\text {-Negative impact of some } \\
\text { incentives such as the density } \\
\text { on urban sustainability. } \\
\text {-Attention to the construction } \\
\text { of housing units at the } \\
\text { expense of services and green } \\
\text { spaces. }\end{array}$ \\
\hline
\end{tabular}

(Source: Author according the references of Scherlowski, 1999; Perera, 2005;Buttiiner, 2006; Cartlidge, 2006; Sengupta, 2006)

\section{The Different Incentives for Private Sector in All Stages of Social Rental Housing Projects}

The offered incentives to the private sector differ from one country to another, according to available resources and financial capabilities for each country. The developed countries are more concerned with the financing incentives, while the developing countries focus on exploiting their existing resources with the least possible financial spending. The World Bank report in 2014 in addition some successful international experiences of countries in rental housing field such as (United State, China, France, Korea, Mexico, Russia, Brazil, Thailand and Russia), showed that there is a need to include the private sector in social housing projects through application some encouraging incentives. In which these incentives combine financial, regulatory and land use incentives, as well as it is suitable for the Egyptian reality that targets the lowest housing unit price, the lowest government funding and the highest returns for the investors. These incentives can be distributed during the different stages of housing project as shown in the following points (Scherlowski. 1999; MIDNR, 2001; UN-HABITAT, 2003; Perera, 2005; Sengupta, 2006; Kofner, 2009; Kemp and Stefan, 2010; EIBoghdady, 2011; Kolsteren, 2012; UN-Habitat, 2012; City of Vancouver; 2012; Lewchuk, 2013; City of Vancouver, 2014; World Bank, 2014b).

\subsection{Incentives in the First Stage (Pre-partnership between the State and Private Sector)}

These incentives reflect the favourable environment from legal and regulatory systems for stimulating the private sector to put his decision about the investment in low-income housing projects, the following points show these incentives (Scherlowski, 1999; UN-HABITAT, 2003):

- Providing organized regulations for investment in housing sector. 


\section{Macrothink}

- Development the current laws of building and planning for achieving the lowest cost of land development in housing projects.

- Establishing governmental institutions to provide supporting and facilities for investors.

- Developing clear plans for housing projects, in terms of project location and targeted number of housing units according to the size of demand and the possibilities of implementation.

- Applying recommendations of international reports and successful experiences in partnership principles.

- Formulation the appropriate partnership contracts with the private sector, which determine (contract type- role of each partner-time of contract- financing- risks and ways to overcome them).

- Determining available financial allocations in the state budget for implementation proposed housing projects.

- Determining the framework of financing and the role of the financing institutions such as banks and mortgage companies in housing projects.

- Putting conditions for selection the type of beneficiaries of housing projects to ensure that only low-income groups benefit from these projects and they have ability to bear the costs of buying or renting housing units without any burdens.

- Determining suitable prices ceiling for residential units that suit with low-income level and achieve profitability for investors at the same time.

- Building criteria of selection the investors to participate in housing projects according to their sufficient experience, funding and commitment in implementing the projects.

\subsection{Incentives in the Second Stage (Preparation for Housing Project by Private Sector)}

In this stage, the private sector decides to participate in the low-income housing project, as a result of a suitable investment climate in the state. In addition, he begins to choose project location and prepares it through additional government incentives such as (Scherlowski, 1999).

\subsubsection{Selection Suitable Land Area for the Private Sector Development Capacity}

The government offers different land areas for the real estate companies, which are commensurate with their technical and financial ability in implementation the housing projects on time and with the standard specifications. Those areas should not be less than 100 acres to have returns for investors and not more than 2000 acres to make controlling on the real estate market by the state (UN-HABITAT, 2003; ElBoghdady, 2011).

\subsubsection{Offering Land with Utilities and Infrastructure}

Equipped land with utilities and infrastructure is an important incentive for investors to 
reduce the cost and the time of development, due to the high cost of infrastructure networks.

4.2.3 Allocation Land at Subsidized Prices for Investors

The government allocates land at lower price than the market price to investors, for reducing the price of housing unit in the social housing project in comparison with its counterparts in the market, in addition to making a suitable profit for the investors.

\subsubsection{Granting Land for Building Social Housing Units (Free of Charge)}

This incentive is used often in social rental or low-priced housing projects, which need to not load the price of land on housing unit price to fit with low-income groups. On the other side, this incentive helps in reducing costs and increasing the profitability for investors (CODI, 2009).

\subsubsection{Exemptions from Assessed Taxes}

Tax exemption is an important incentive for investors in the field of real estate, whether the taxes on the establishing new real estate companies or taxes on land and buildings in housing projects, to support low-cost housing projects.

\subsubsection{Exemptions or Reduction from the Development Fees}

The real estate developers have exemptions or reduction from some fees, which are paid to the municipality, in exchange for building number of low-income housing units as part of the proposed development plan of the site. These fees are (zoning fees-fees of submitting concept, initial plan, final plan and subdivision plan-site plan fees-plan revision fees-building permits fees-utility fees). The exemption is applied to initial development fees, while the reduction is applied to the site development fees, which its ratio reaches nearly $50 \%$.

\subsubsection{Paying Extra Fees Instead of Building Low-income Housing Units in the Site}

The investor pays all development fees without any reduction, besides extra fees instead of establishing low-income housing units in allocated land. These fees are deposited in housing fund for using them in future government housing projects.

\subsubsection{Facilities in the Administrative Procedures and the Licensing Requirements}

Government institutions concern with applying the facilities, in all administrative procedures of housing project and try to review the urgent licensing of land division and building in faster time, than usual if the project includes housing units for low-income.

\subsubsection{Technical and Consulting Support}

The state provides technical and consulting support during all stages of housing project to get well design and implement the project with distinguished and efficient specifications.

\subsection{Incentives in the Third Stage (Financing the Housing Project)}

These incentives relate to providing the investor adequate liquidity to finance low-income housing projects. Through the state, banks, real estate financing companies and housing funds 
as shown in the following points:

\subsubsection{Direct Government Financing}

Direct financing is used in the case of existence sufficient financial allocations from government, to build urgent low-income housing units through the participation with private sector, who has a role in providing additional funding and experience in planning, design and construction.

\subsubsection{Long-term Soft Loans with Low Interest Rates}

Many financing bodies such as banks, financing companies and housing trust funds, grant soft loans to investors for low-income housing projects with low interest rates (not exceeding $5 \%$ ). In return of submitting letter of guarantee from (properties, capital or built social housing units), to control the process of selling by the government and deliver these units to real beneficiaries at the right price. These loans are covered by the revenues from selling or renting residential units, commercial and service activities in housing projects.

\subsubsection{Fixing the Interest Rates of Loans during the Implementation Process}

The interest on the loans is fixed throughout the period of project implementation until sufficient liquidity is available and the investor gets profit from the project.

\subsection{Incentives in the Fourth Stage (Implementation the Housing Project)}

Incentives during this stage focus on helping the investors for implementation the social housing project at the least time and cost with high profit, by using land use incentives in executive project plan, as shown in the following points:

\subsubsection{Density Bonus in the Same Project}

It is one of offered incentives to real estate developers, which means the possibility of increasing the number of buildings and housing units (residential density) than specified density in the plan as shown in figure no (3). This is applied through the approval of government agencies to increase the development area in accordance with city policies and without any negative impact on the population or surrounding areas. There are many ways of applying this incentive, the first one is increasing the building density ratio or building ratio in the allocated part of social housing. While the second way is raising housing density in the area of medium and high housing in return for building more units for low-income groups. This incentive useful for covering increased housing demand and addressing the financing problems (MDNR, 2001).

\subsubsection{Zoning Code for Housing Project}

Zoning code determines the requirements for each housing area from (land use typesdensity- building ratio- building heights- design of housing units- number of housing units for each group..). This incentive directs the investors to provide more units in some zones only and apply restrictions in others to preserve them for social and environmental purposes as shown in figure no (4) (Chen, 2010; Rodrigue, 2017). 


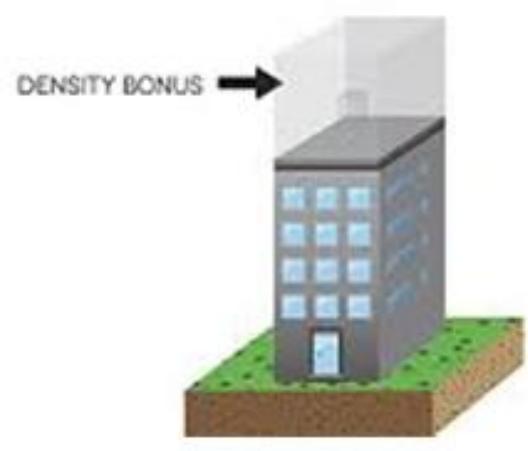

Figure 3. Density Bonus incentive in low income housing projects

(Source: City of North Vancouver, 2019)

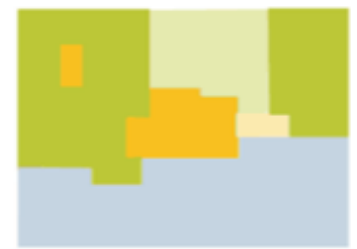

- A zone for each type of land use.

- Land use zones subject to different regulations.

Figure 4. Zoning Code incentive in low income housing projects

(Source: Rodrigue,2017)

\subsubsection{Identifying Limited Number of Housing Units for Social Housing}

The developer offers one social housing unit from every ten built housing units, in return for some privileges such as tax exemptions, fee reductions, flexible planning and design criteria, raising density or facilitating in repayment. These social housing units are provided during some stages according to the total housing demand in each city.

\subsubsection{Diversity in Housing Units Types}

The State aims to achieve diversity in housing units types and their areas, within the same residential area to reach a suitable profit margin for the private sector, and reduce social differences between the population as shown in figure no (5) (Chen, 2010).

\subsubsection{Mixed Land Use}

Mixed land use offers the best exploiting of land value and achieves the highest economic returns, by allowing the commercial and service activities to be with the residential use. On the other hand, it contributes in providing the main needs of the population in the same area, and reduces the costs of moving to and from the areas of services and work as shown in figure no (6) (MDNR,2001). 


\section{Macrothink}

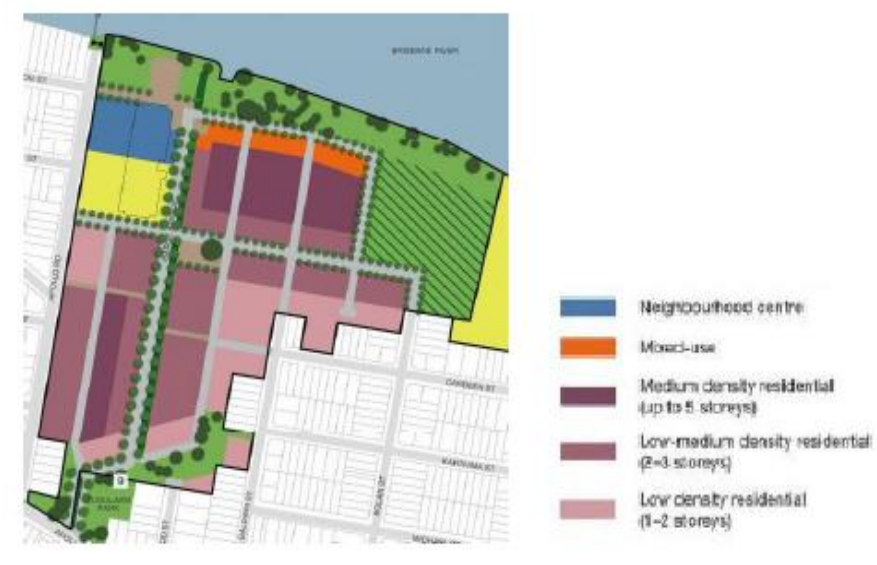

Figure 5. Diversity in housing units for low income housing projects

(Source: Master planning for rare, north-facing riverfront land, 2019)

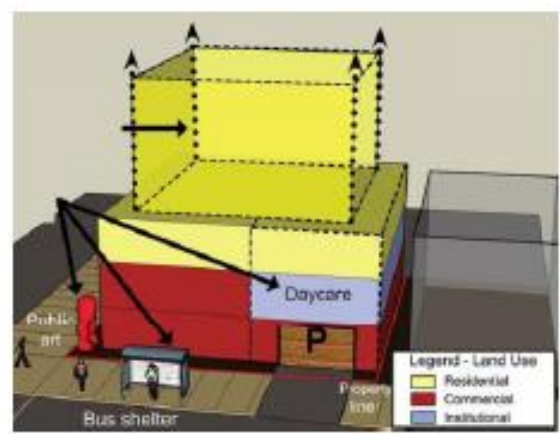

Figure 6. Mixed land use incentive in low income housing projects

(Source: Verde land \& Water Planning Toolbox, 2016)

\subsubsection{Introducing a Flexible Plan for Housing Project}

The flexible land use plan for the social housing project is one of the most important incentives for the developer to cover his costs, solve funding problems, meet changing needs of population and benefit from the changes in land values, in favor of future development and project expansion without prejudice to sustainability criteria.

\subsubsection{The Economics of Housing Units Design}

The State presents design for housing units are characterized by flexibility for future needs, achieving economies of form and function, and the ease of implementation process at minimal cost.

\subsubsection{Minimizing the Percentage of Spaces, Green Areas and Parking in Housing Project}

The State puts some incentives related to the possibility of reducing the percentage of green areas, private spaces, parking and roads to a permissible limits in the partnership housing projects, in order to providing more housing units and covering the high expenses as shown in figure no (7).

\subsubsection{Minimizing Land Plot Area of Social Housing}

This incentive means dividing the site of the social housing project into small land plots and building on the large percentage of land plot. To increase the number of residential buildings in the same project, provide better area for housing units, achieve the lowest price per housing unit and increase the profitability level as shown in figure no (8). 


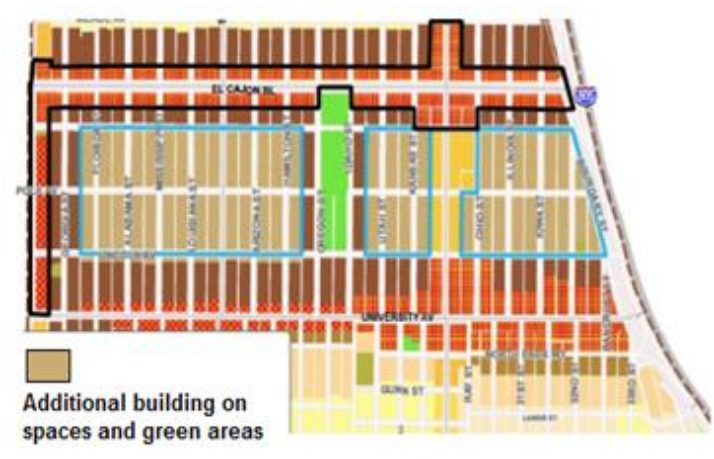

Figure 7. Minimizing spaces, green areas and parking for building housing project

(Source: Density Bonus plan of North
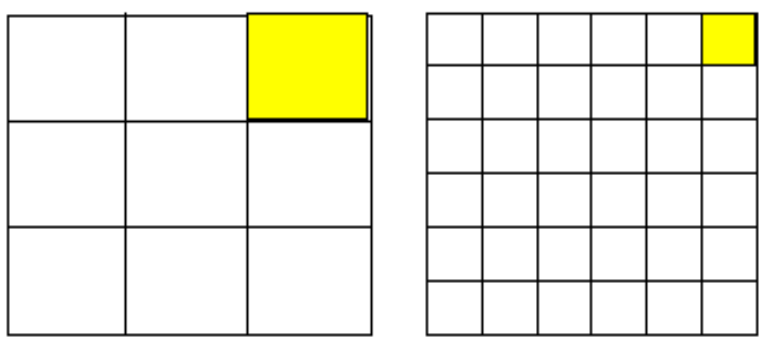

Figure 8. Incentive of minimizing land plot area in low income housing project

(Source: Author)

Park,2016)

\subsubsection{Reducing the Required Area for Social Housing Project}

The state reduces the required area for social housing, which its ratio does not exceed 20 or $30 \%$ from the total project area as shown in figure no (9), to give an opportunity for developing the investment uses and achieving a higher level of profitability.

\subsubsection{Providing Advanced Systems for Building Housing Units at Subsidized Prices}

The State aims to provide the requirements of building the new housing units, from sophisticated systems and subsidized prices to reduce the costs and required time for their implementation, through using cheap prefabricated construction units as shown in figure no (10) (UN-Habitat, 2012).

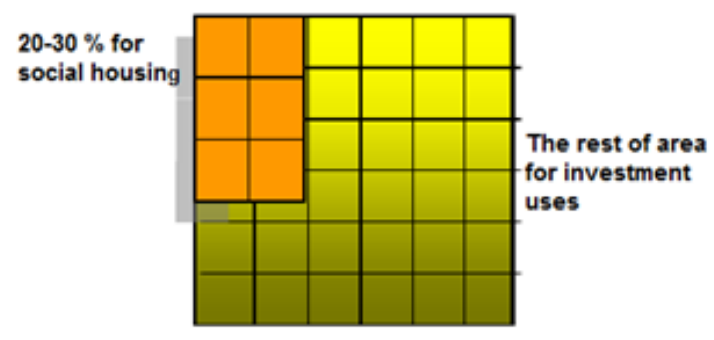

Figure 9. Reducing the required area for social housing project

(Source: Author)

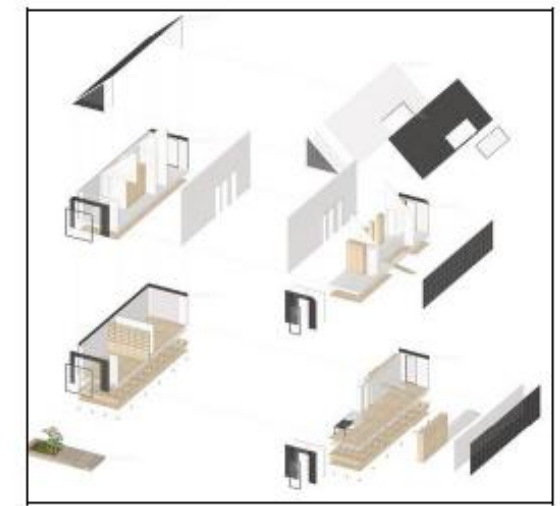

Figure 10. Prefabricated construction process for low income housing projects

(Source: Prefabricated Social Housing, 2019) 


\section{MInstitute Macrothink}

\subsubsection{Implementation Social Housing Project over Stages}

This incentive allows to implementsocial housing project over some phases according toits priority, size of available funding and housing demand. At the same time, the percentage of the implemented units in the first phases should not less than $30 \%$ of the total required units in the project.

\subsubsection{Determination Appropriate Time for Implementation the Social Housing Project}

The appropriate time for implementation the social housing project should be two years at least according to the project size and the availability of financing, to avoid the problems and risks for investors.

\subsection{Incentives in the Fifth Stages (Follow-Up and Marketing)}

The incentives of this stage come after the implementation stage to identify the mechanisms of marketing, follow-up and management the housing project. In order to ensure the achievement of project objectives and obtaining the satisfactory returns for investors, as shown in these points:

\subsubsection{Advertising and Marketing of Housing Units}

The state undertakes the advertising and marketing the social housing units, to sell them in the shortest possible time and ensure that target low-income group is the real beneficiary from those units.

\subsubsection{Allow To Rent Some Implemented Social Housing Units for Short Time}

The investor can benefit from leasing some implemented social housing for a short period, in order to finance construction the rest of required units and increase the project returns.

\subsubsection{Long Time of Exploiting Social Housing Project}

This period means the period of operation the project, in which investors can benefit from social housing project and maximize his revenue, before the ownership is transferred to the state again. This period must not be less than five years.

\subsubsection{Controlling the Time of Sales and Leasing Social Housing Project}

This incentive helps sometimes the investor to sell implemented housing units, when the offered price is suitable for covering costs and achieving a suitable margin profit for him.

\subsubsection{Providing Financial Support for Selling Social Housing Units at Subsidized Prices}

The state pays the value of project profit to real estate developers, in exchange for selling social housing units at subsidized prices below the market price, to be suitable for low-income social groups (Burda, 2013; Aribigbola, 2008).

\subsubsection{Supervise, Follow Up, Maintain and Address Project Risks}

The incentives of state towards investors extend to supervision, follow-up, maintenance and bearing some housing project risks, to ensure that the project achieves the objectives of the 
state, investors and population.

The following figure no (11) shows the incentives that can be provided by the state to investors during the different stages of social housing project, with determination the role of each entity in these incentives.

\begin{tabular}{|c|c|c|c|c|c|}
\hline \multicolumn{3}{|c|}{ The stage of pre-partnership } & \multicolumn{3}{|c|}{ preparation for housing project by private sector } \\
\hline $\begin{array}{l}\text { regulations of } \\
\text { investment, planning } \\
\text { and deign }\end{array}$ & $\begin{array}{l}\text { Plans for housing } \\
\text { projects }\end{array}$ & $\begin{array}{c}\text { governmental } \\
\text { institutions for } \\
\text { PpP }\end{array}$ & Suitable land area & $\begin{array}{l}\text { Granting land } \\
\text { (free of charge) }\end{array}$ & $\begin{array}{c}\text { Paying fees } \\
\text { instcad of } \\
\text { building social } \\
\text { housing }\end{array}$ \\
\hline $\begin{array}{l}\text { Using international } \\
\text { reports and } \\
\text { successful } \\
\text { experiences }\end{array}$ & $\begin{array}{l}\text { Formulation } \\
\text { partnership } \\
\text { contracts }\end{array}$ & $\begin{array}{l}\text { framework of } \\
\text { financing }\end{array}$ & $\begin{array}{l}\text { Offering land with } \\
\text { utilities and } \\
\text { infrastructure }\end{array}$ & Tax Exemptions & $\begin{array}{c}\text { Facilitate the } \\
\text { administrative } \\
\text { procedures }\end{array}$ \\
\hline $\begin{array}{l}\text { Identify beneficiaries } \\
\text { of social housing } \\
\text { project }\end{array}$ & $\begin{array}{c}\text { Control the price } \\
\text { ceiling of housing } \\
\text { unit }\end{array}$ & $\begin{array}{l}\text { Principles of } \\
\text { partnership }\end{array}$ & $\begin{array}{l}\text { Allocation land at } \\
\text { subsidized prices }\end{array}$ & $\begin{array}{c}\text { Fees } \\
\text { exemptions or } \\
\text { reduction }\end{array}$ & $\begin{array}{l}\text { Technical and } \\
\text { consulting } \\
\text { support }\end{array}$ \\
\hline
\end{tabular}

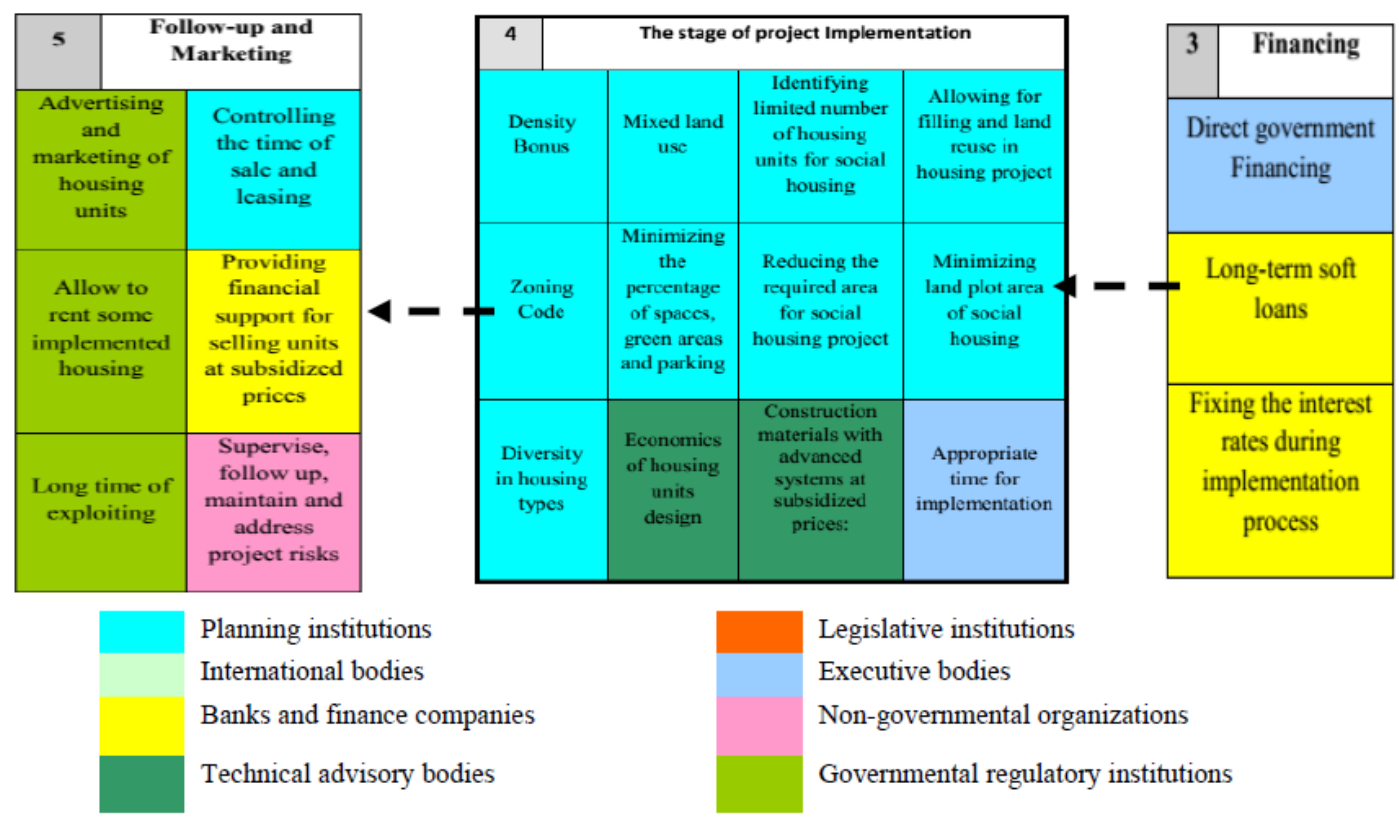

Figure 11.Different incentives for private sector in all stages of social rental housing projects, besides the role of each entity in these incentives

(Source: Author)

\section{Incentives for Private Sector in New Egyptian Cities:}

\subsection{Evolution of the Incentives System in Egyptian Low-income Housing Projects:}

The idea of applying incentives in housing projects has emerged, after the private sector withdrew from the participation in subsidized housing market. Due to the lack of sufficient profitability in this type of housing projects. For this reason, the Egyptian government had the responsibility of providing these units from 1961 to the war of October 1973. In which the 


\section{Mll Macrothink}

Environmental Management and Sustainable Development

ISSN 2164-7682

2020, Vol. 9, No. 1

Egyptian government spent a large public budget in housing sector compared to other economic sectors (World Bank, 2014a).

Therefore, the state has put some incentives for developers after 1973, such as facilities in land acquisition and construction process to speed up the development of housing projects, by using other non-governmental funding sources to meet the increasing housing needs. From this year the private sector played the main role in housing market, especially for middle and high income groups, who have ability to buy high-priced housing units (USAID, 2007; World Bank, 2014a).

On the other side, there is growing in the low-income housing demand compared to other housing categories, which led to thinking about Mubarak Youth Housing Project in 1995 and National housing project (Mubarak National Housing Project) in 2005. Where the state has participated with the private sector in low-income housing projects as one of the seven axes of this project (titling housing unites- granting land for Ebny Betk- Sale land for investorsBet al alaela project- Awlabel-re'aya project- rental housing units- rural housing units). During this project the government provided some incentives for private companies like, land provision with basic infrastructure and selling it at subsidized prices ( 70 pounds for meter), in exchange for building low-income housing units $\left(63 \mathrm{~m}^{2}\right.$ for each unit), on the half of total area within two years and the rest area are dedicated to other social groups to achieve a suitable profit (El-Demery, 2002; USAID, 2007; World Bank, 2008).

However, these incentives were not enough to make the private sectors able to build required low-income housing units within the specified period or solve construction challenges. Moreover, the implemented low-income residential units by the private sector were characterized by high prices, which reached to 147 thousand pounds per unit, despite its actual cost is approximately 70 thousand pounds. Each beneficiary in these projects has about LE 25.000 as government support and pays LE 10.000 as the applicant of the unit's reservation. In addition to paying LE 47.000 at allocation time and the rest of price on installments for four years, which reached to more than 2000 LE per month). This price is not commensurate with low incomes or the goals of the National project. For these reasons, the incentives have evolved to include 10-year repayment facilities with $10 \%$ interest rate and three years grace period for investors in low-income housing projects to provide affordable housing units. The implemented units by the private sector during this period accounted about $14 \%$ from the total units of Mubarak National Project in 2005 (85 thousand housing units with titling system) (El-Demery, 2002; USAID, 2007; World Bank,2008; World Bank,2009; World Bank,2014a).

Social housing project appeared in 2011 and was implemented in 2014 with the assistance of private sector, based on the Constitution of the Arab Republic of Egypt in 2014 (article no 36), which referred to the importance of stimulating the private sector to do his social responsibility in serving the national economy and society. Accordingly, the social housing projects used new modified incentives to increase private sector participation such as (providing land with large areas of up to 2,000 acres according to the company size- reducing the proportion of required area for building social housing units to only $30 \%$ instead of $50 \%$ 
of the total land area to achieve margin greater profit). At the same time, the state benefited from the participation of the private sector through (available financial liquidity- his experience in planning and design- his contribution in increasing the production of housing units for low-income) (World Bank, 2014a; MHUUC, 2016).

In the year of 2016, social housing project expanded and the size of projects exceeded the financial capacity of most private companies, leading to the inclusion of banks as financing institutions for example, Housing \& Development Bank, Bank Misr and Bank El Cairo to provide the necessary loans at low interest rate for private sector to complete the project on time. In spite of previous incentives, the private sector faced a number of obstacles in social housing projects such as (the short time of project implementation, inadequate incentives, high cost of building, lack of government support in providing cheap construction materials or facilitation the procedures and licenses- inflexibility legislative and regulatory frameworkunprofitable land uses in social housing project), these reasons led many real estate companies decline from participating in this project and unwilling to repeat the experience again (MHUUC,2016).

As a result of that, in 2018 there was cooperation between many actors of real estate development, such as (the Ministry of investment and international cooperation- Ministry of Housing- the World Bank- some leaders of the social housing fund and mortgage finance- the Chamber of Real Estate Development in Federation of Egyptian Industries (FEI)- Real Estate Investment Department- the Egyptian Real Estate Council), to motivate the private sector to participate in new social housing projects, through some new incentives which achieve the balance between the goals of the state and investors, through the following:

- Allocation land at suitable price for real estate developers, who have experience in the field of housing projects.

- The provided land is divided into two parts, the first part is called "free part" for medium and high housing units with an area of $\left(90-150 \mathrm{~m}^{2}\right)$, in which their price are determined by the pricing committees in each city. While the second part is for social housing units with an area of $63 \mathrm{~m}^{2}$ and their price are determined by the terms of social housing program.

- Allowing to exploit large area for investment uses, compared to the allocated area for social housing project (30\% only for social housing project).

- Providing facilities in land price payment during a set of annual instalments.

- Existence of different methods of repayment (cash or in kind).

- Providing adequate funding in return for provision number of social housing units at an appropriate price to cover the expected housing demand.

- The duration of implementation the social housing project does not exceed 3 years.

- The cost of implemented social housing units is equal the total value of allocated land for investment uses, and the property of social housing project remains for the state. 
- Provide a letter of guarantee with (25\% of the total project cost).

- Allow to implement services in the project (12\% from the total project area), which serve the whole of neighbourhood not only the project.

Recently, in June 2019 real estate developers have submitted some recommendations for their participation in social housing projects, these recommendations including, (establishment of commercial areas on $12 \%$ of the total project area- facilitating procedures for registering the residential units and reducing their registration costs- constructing residential communities with different housing units levels in the same project location- reducing the area of social housing units and increasing their numbers with the density-eliminate the interest support and reliance totally on cash support- abolition the letter of guarantee- make the mechanism of sale is done through the government to ensure good marketing for housing units- improve the environment of investment and provide all laws that facilitate development process for investors).

Nowadays, the Ministry of Housingproposes additional incentives for investors that have not yet been applied such as:

- Allocation land for free of charge in return of provision social housing units, with the same value of granted land to not load the land price on housing unit price. While the land ownership of social housing project remains for the state.

- The investor obtains the land for investment uses at the market price, which is determined by thepricing committeein New Urban Communities Authority, according to the characteristics of each city. In addition, the land price is paid through $10 \%$ down payment with a period of three years grace and the rest of price over seven years.

- Allocating the ground floors of social housing building to implement commercial shops and administrative units.

- Specifying $12 \%$ of investment project area for commercial uses to provide financial gains for companies and increase their ability to implement social housing projects.

- Grant land gradually with building process of low-income housing units, to ensure from the seriousness of real estate companies.

Finally, the state is still studying the appropriate incentives for the private sector in the field of social housing, which achieve suitable margin profit for him and high achievement for state goals at lowest cost. The following figure no (12) shows the evolution of incentives system in Egyptian social housing projects. 


\section{$\triangle$ Macrothink}

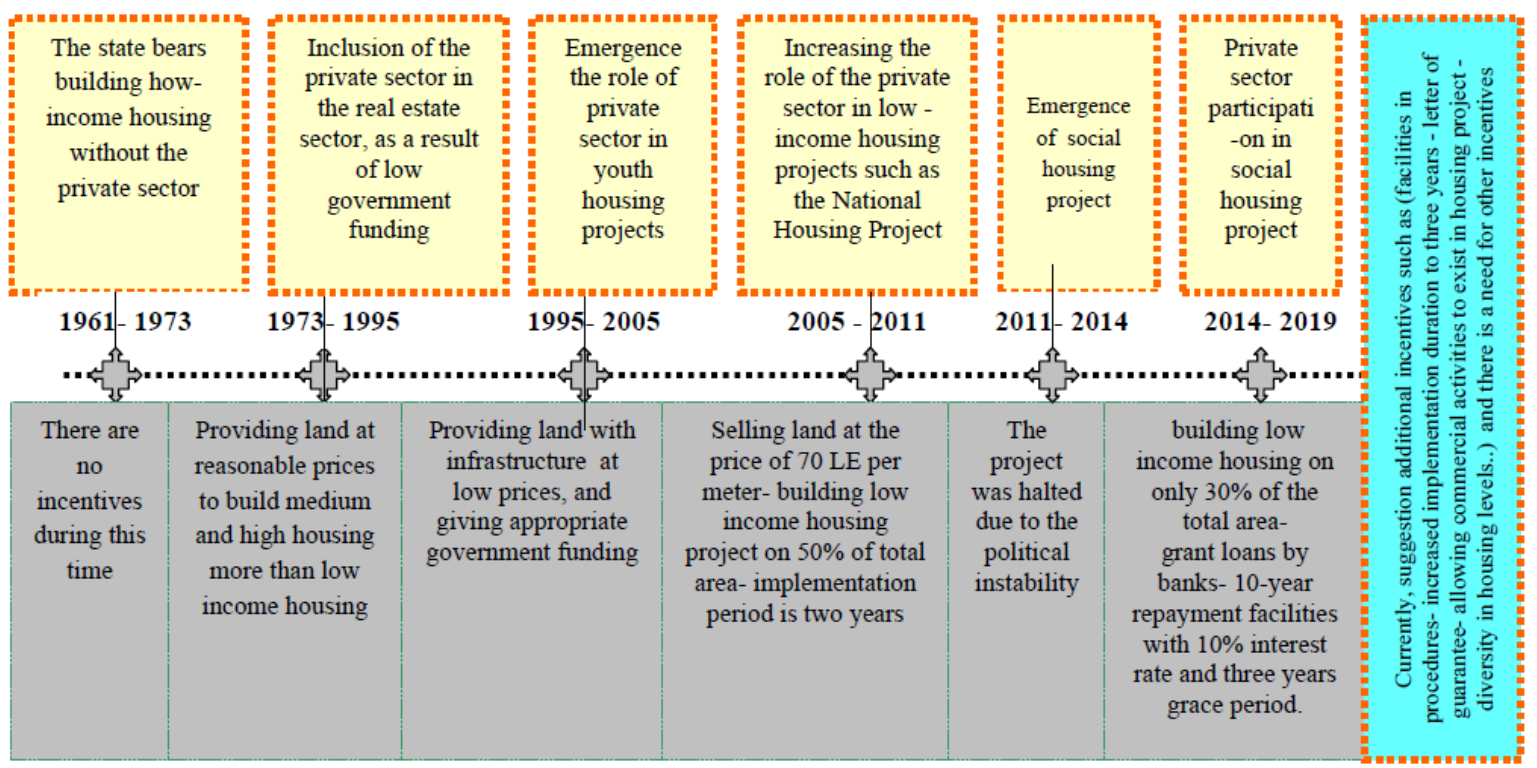

Figure 12. The evolution of incentives system for private sector in Egyptian social housing projects

(Source: Author according to the references of USAID, 2007; World Bank, 2008; World Bank, 2009; World Bank, 2014a; MHUUC, 2016)

\subsection{The Legislative Framework of Incentives in Egyptian Social Housing Projects}

There are many laws determine the most important incentives that the state can provide to the private sector to invest in the field of social housing as shown in figure (13). Most laws focus on financial and regulatory incentives to support the low-income housing sector. For example, the law of financing economic housing projects No. 107 of 1976, the decision of the Minister of Housing to establish a fund for the financing of economic housing projects and the Prime Minister's decision No. 745 of 1995 to manage the economic housing (Law No 107, 1976).

The second law is the law of PPP No. 67 for 2010 and the resolution of the Council of Ministers No. 238 of 2011, which regulate the participation of private sector in infrastructure projects, services and public utilities. Through specific contracts between the administrative authorities and the private sector to carry out specific tasks such as financing, construction, processing, operation and maintenance for some projects during the contract period. These tasks may go beyond the full exploitation of the project with the follow-up from administrative authorities, according to some specified criteria (Law No 67, 2010).

This law clarifies some bodies such as High Committee for Participation Affairs, which organizes the participation process and offeres the incentives to create an enabling environment for participation, through its important tasks like (drawing up the general policy of partnership and defining its objectives and mechanisms- approval the partnership projectsadoption the application of participation system and its standards- proposing a funding structure for partnership- identifying suitable contract for each partnership project that 
includes the role of all parties, properties limits, risk allocation, contract duration which not less than five years and not more than 30 years, project recovery rules and monitoring toolsfollow up the financial allocations for implementation the partnership contracts- provide the mechanisms of appropriate market for participation). (Law No 67, 2010).

The second body is Central Unit of Participation, which provide (technical, financial and legal expertise for High Committee for Participation Affairs- prepare necessary studies and information for participation project- suggest legislative frameworks to organize the partnership process) (Law No 67, 2010; Ministry of Finance, 2015).

The other law is Real Estate Finance Law No. 55 of 2014 that is an amendment to some articles of Law No. 148 of 2001, law No. 143 of 2004 and law No. 10 of 2009. This law clarifies the incentives of real estate finance for investors in the field of economic housing through competencies of the following entities: (Law No 55, 2014).

- The Egyptian Financial Supervisory Authority (EFSA) specializes in real estate finance for buying, building, renovating and developing housing. This Authority provides an appropriate amount of funding according to the project size and the investor financial capacity in return for an acceptable guarantee.

- In the case of economic housing projects, the state allocates land for free of charge to establish low-income housing and the state bears all or part of utilities costs for these houses, besides other subsidies forms.

- There are facilities in paying the finance, through installments and there is possibility in reducing its value in the case of prepayment.

- The non-compliance with any of contract terms or non-payment within the specified date leads to booking on guarantee.

- The Real Estate Guarantee and Support Fund payspart of monthly installment instead of the population due to their low incomes.

- Existence of offices receive and examine complaints, foreshadow irregularities and stop the real estate activities as a result of non-compliance with funding conditions.

In 2016 the Council of Ministers referred in his resolution No. 8 that social housing units in different governorates are implemented by investment companies through a set of incentives, such as (allocation land for investment activity which its price equal the total cost of implementation the number of social housing buildings- the total area of allocated land for social housing is not less than $30 \%$ from the total project area) (MHUUC, 2016).

The new investment law No. 72 for 2017 added a number of incentives as a development of investment law No. 8 of 1997. These incentives appeared in the second part of this law (the section of investment guarantees and incentives), towards any investment project in the sector of industry, agriculture, trade, education, transport, tourism and housing, through some institutions such as: (Law No 72, 2017). 


\section{Macrothink}

- Investors Services Centre (an administrative unit in the General Authority for Investment or in one of its branches), this centre facilitates and simplifies procedures for investors to obtain all necessary approvals, licenses, information and data for their investment project.

- Accreditation offices (licensed by the General Authority for Investment), which grant approvals, permits and licenses besides examining the procedures and documents of the investment project to provide the accreditation certificate.

- The General Authority for Investment helps the private sector to participate in development projects by its tasks that including (Preparing the investment plan by cooperation with all the competent state bodies to determine the type of investment and its geographical areas in all development sectors- developing plans and studies that attract and encourage national and foreign capitals for investment in various field- putting investment opportunities and targeted investment projects- proposing related legislation to investment).

The Authority of Investment offers also additional incentives in the form of (EFSA, 2014):

- Exemption from stamp duty and notarization fees for five years, to establish new real estate companies.

- Exemption from the taxation of land registration contracts for building real estate companies.

- Deduction from net taxable profits of up to (30\%) from the investment costs, which is not exceed $80 \%$ from paid capital according to the tax law No. 91 for 2005.

- The state bears the value of what the investor costs to deliver facilities in his investment project (or part of this cost).

- The state allocates land (free of charge) for strategic activities within the investment project.

- The state deducts from the taxes what investors spend for social development within his project, which is not exceeded $10 \%$ of his annual net profits.

- In the case of dispute between the investors and the state, the Egyptian Center for Arbitration and Mediation settles these disputes and puts solutions to facilitate the investment process.

The other law is Social Housing and Mortgage Support No. 93 of 2018 (development of Law No. 33 of 2014), identifies other incentives for investors in the social housing sector through some entities such as (Law No 93, 2018):

- The Ministry of Housing, Utilities and New Urban Communities which proposes plans, launches and supervises the social housing projects to provide adequate housing for low-income social groups with a maximum of $120 \mathrm{~m}^{2}$ for housing unit. 


\section{Macrothink}

- The Social Housing Fund is responsible for all the funds and assets of the Social Housing Finance Fund and Real Estate Finance Guarantee and Support Fund, besides all land and buildings of social housing for low and middle-income groups.

- This Fund finances, manages, constructs, sells and leases housing units, commercial, services and activities in the social housing program. In addition to its role in formulation the required general policies for social housing program, determination utilization systems in this program (ownership- permanent or temporary rent) and setting appropriate support values for population and investors.

- The Fund coordinates with the New Urban Communities Authority, the Financial Supervisory Authority and the concerned authorities to provide social housing and put incentives for private sector to build low-cost social housing units with a satisfactory return.

Finally, there are some other laws that set the regulatory and detailed framework for dealing with land within housing projects, such as the New Urban Communities Law No. 59 of 1979, which regulates the role of the state towards dealing with land inside new cities and prepares the detailed plans for housing projects (Law No 59, 1979)..In addition to the Unified Building Law No. 119 of 2008, which puts the requirements for different areas within the city and helps in the development of related incentives to land use within housing projects (Law No 119, 2008).

\subsection{Responsible Entities for the Incentives of the Low-income Housing Project in New Cities}

Many entities play a main role in attracting the private sector to low-income housing projects in new cities, especially during the period of the eighties and nineties. The following figure (14) collects these involved actors and entitiesthat have a planning, financing, organizational, executive and legislative rolein the incentives system.

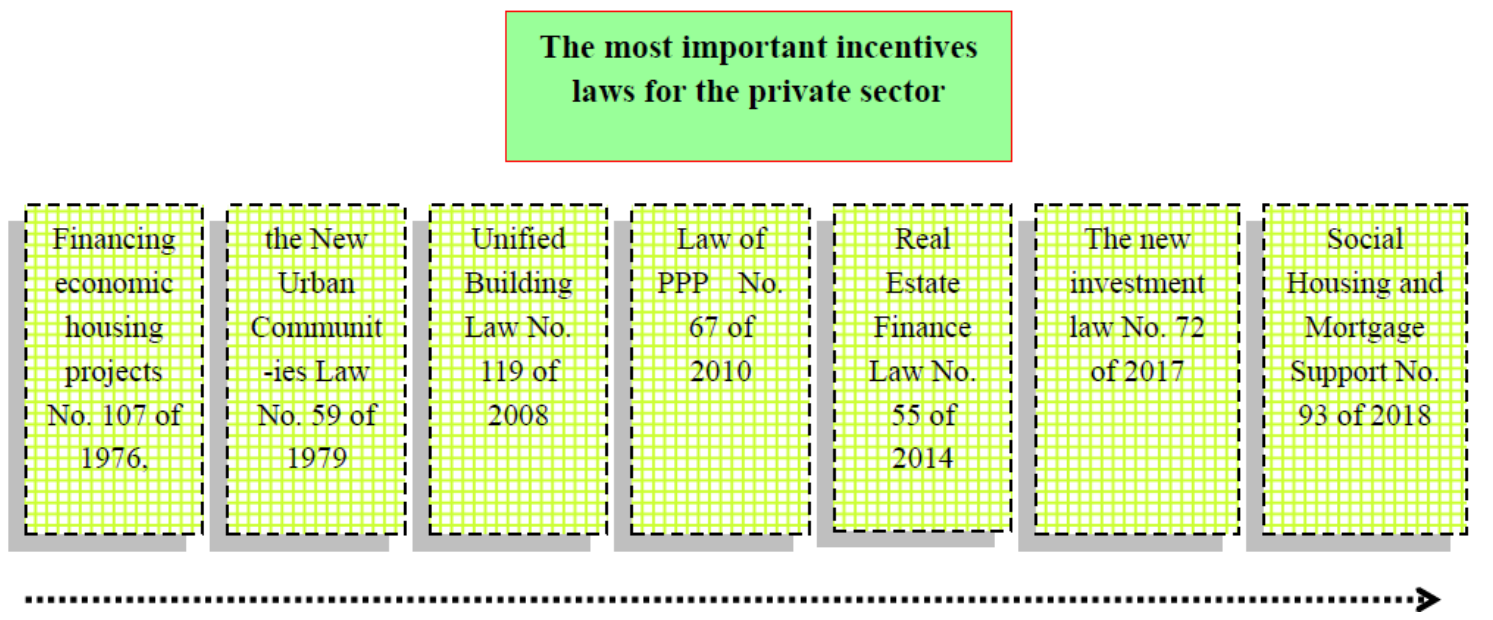

Figure 13. Laws of incentives for private sector in housing projects

(Source: Author) 


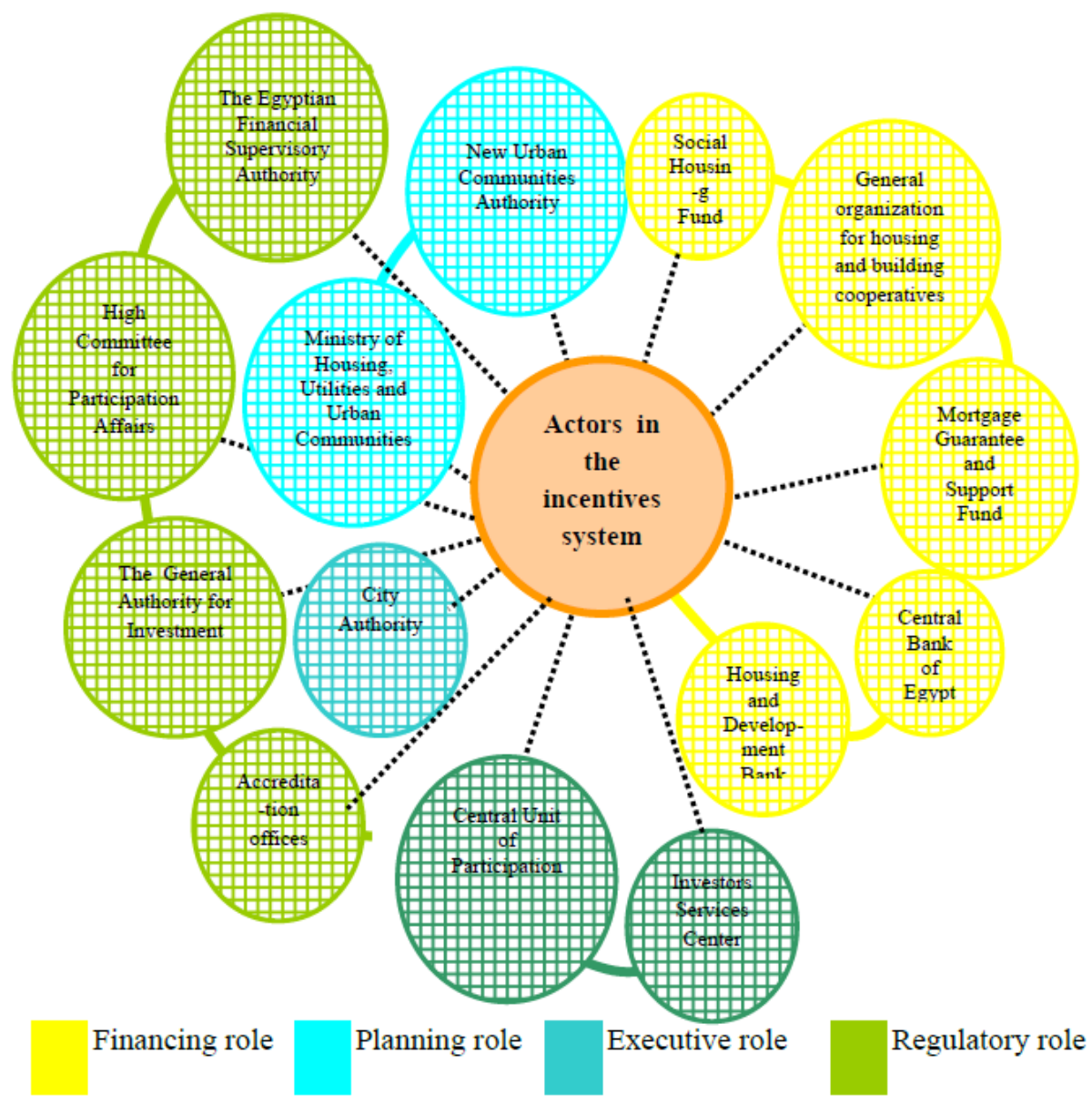

Figure 14. The most important involved actors in incentives system for social housing projects in new cities

(Source: Author according to the references of USAID, 2007; EFSA, 2014; MHUUC, 2016)

\section{The Role of the Private Sector in Low-income Housing Projects in the New Egyptian} Cities

During the 1980s and 1990s, the Ministry of Housing and New Urban Communities shifted to establishing new cities and attracting investors to finance and build housing units for different social groups, to reduce the informal housing in existing cities and provide a suitable living condition in new cites. In this period, the private sector contributed towards building about $45 \%$ of total housing units, which were for medium and distinguished housing. (USAID, 2007)

Low-cost housing projects clearly emerged through the Mubarak Youth Housing Project in 1995. In which About 100,000 housing units were built through the Youth Authority of the New Urban Communities Authority (NUCA) (CAPMAS, 2006), 16\% of these housing units were funded by the private sector and the rest by government grants and loans from bank. In this project, the real estate companies built the subsidized housing units on $50 \%$ of total 
allocated land and then sold them to the citizens who meet the conditions of the Ministry of Housing. Most of these housing units are concentrated in the cities of Six October and Badr (USAID, 2006; World Bank, 2008; World Bank, 2009; World Bank, 2014a).

In 2005, the State adopted the implementation of the National Housing Project known as Eskan Mubarak for low-income housing. The project aimed to establish 500,000 low-income housing units with an area of $63 \mathrm{~m}^{2}$ during 6 years (2005-2011) and through seven axes. The participation of the private sector was one of these axes to increase the housing production, in which the government provided incentives for private sector such as financial support, besides land with infrastructure at the price of 70 pounds per meter for building low price housing units. In this project about 6148 acres were allocated to 37 real estate companies that have experience in housing development to build about 300 thousand housing units in 14 cities (Six October- Sheikh Zayed- El Shorouk- Badr- El Obour- 10th of Ramadan- New Borg El Arab- Sadat- New BeniSuef - New Minya- New Qena- New Assiut- New Aswan), but only 85 thousand housing units were implemented during this period due to high construction costs, short duration of implementation and difficulties in administrative and organizational procedures (USAID, 2007).

Many real estate companies obtained land from the state for building low-income housing units, within the National Housing Project in the new cities, including Orascom Housing Cooperative Company, Rabwa Real Estate Investment Company, Elarbea Company for Urban Development, Mena for Future Housing, Alnoor for contracting, El Batal for Housing \& Development and Mimar Al Morshedy Company (Abouelmagd et al., 2013).

The cities of Sheikh Zayed and Six October occupied most of the private sector projects, including the Rawda Zayed project in Sheikh Zayed, where 82.5 acres were allocated to Elofoq Real Estate Investment Company to build housing units for low-income (about 1500 units) on $50 \%$ of total area (41 acres). In addition to projects in October gardens such as Degla Garden project and Montazah project, which were allocated 100 acres to each project (CAPMAS, 2019).

The role of the private sector in the National Housing Project ceased after the revolution of January 2011, until the emergence of the social housing project in 2014. Where the state was the real estate developer to build about million housing units for different levels (socialmedium- high), 725 thousand units from these units are for low-income housing that are distributed in 22 new cities (Abouelmagd et al., 2013; CAPMAS,2019).

The private sector participated again in some social housing projects from the year of 2016 until now, which are represented in:

- Subsidized social housing $\left(65-90 \mathrm{~m}^{2}\right)$ for the people, who have income between (1500 to 4750 ) pounds per month, this type is the majority of implemented units by private sector in social housing project (125.000 housing units- $68 \%$ from the total implemented units in 2018).

- Unsupported social housing (75 to $95 \mathrm{~m}^{2}$ ), these units represented about $10 \%$ of the total implemented units (18,000 housing units). 


\section{Macrothink Institute ${ }^{\text {tit }}$}

- High-income social housing (Dar Masr) $\left(115 \mathrm{~m}^{2}\right)$, in which the private sector implemented about 40 thousand units $(22 \%$ of the total implemented housing units in this type).

- Rental Social housing $\left(75 \mathrm{~m}^{2}\right)$, the first offering of this type was in 2016 (6000 housing units) over 10 governorates, but private sector has limited participation in this type.

- Rental social housing (90 m2) with cash support, this type is not implemented yet.

The partnership between the state and the private sector in social housing project was through the signing number of contracts between the New Urban Communities Authority and some real estate development companies. The first posing was in 2016 to establish a range of new expansions in some cities for low-income groups, such as the northern expansions of Six October city on an area of 500 acres by the Mountain View ICity Company, Sun City project on an area of 135 acres in October Gardens area and another project in New Cairo), the total area of partnership projects in first posing is about 2363 acres (CAPMAS, 2019).

By the end of 2016 , about 183,000 housing units were implemented by the private sector (18\% of the total number of targeted units in the social housing project), and this number has increased to about 240,000 units, according to the Central Agency for Public Mobilization and Statistics in July 2019 (CAPMAS, 2019).

The second posing for companies was in (2017-2018) for six projects, which is (integrated urban project in the north of Sheikh Zayed city on an area of 410 acres- project of mixed activities in Sheikh Zayed City called Zayed Spark area on an area of 205 acres- an integrated urban project in the axis of Dabaa extension of Sheikh Zayed City on an area of 1000 acresan integrated urban project west Sheikh Zayed City on an area of 500 acres- a project in the eastern expansions in Six October city on an area of 144 acres- urban project in the university zone of New Cairo city on an area of 104 acres). Many companies participated in this posing like Ahli Real Estate Development, SODIC and Arkan Palm Real Estate Investment.

The projects of third posing will be in the new cities of El Alamein, New Mansoura, west of Qena, Assiut and the extensions of Six October and Sheikh Zayed. The total allocation land until 2019 is about 6500 acres for 163 companies during all previous stages of social housing, which were distributed in 15 new cities such as (Six October- Sheikh Zayed- 10th of Ramadan- Badr- Obour- Sunrise- New Minya- Sohag- New Assiut- New Qena). To provide about 300 thousand housing units, of which only 126 companies are carrying out their projects. A review of partnership projects between the private sector and the state show that most of the partnership projects appeared during the period from 1996 to 2018 as shown in figure no (15), and these projects appeared clearly in the new cities around greater Cairo, as shown in figure (16), especially October City that has the highest percentage of implemented units by private sector as shown in figure no (17). Therefore, the October City is the best city for studying the incentives in it. 


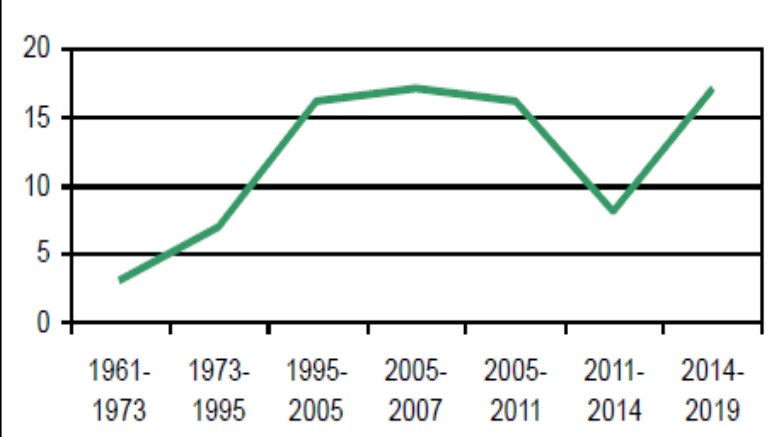

Figure 15. Percentage of private sector participation in low-income housing projects from the year of 1961 until now

(Source:CAPMAS,2019)

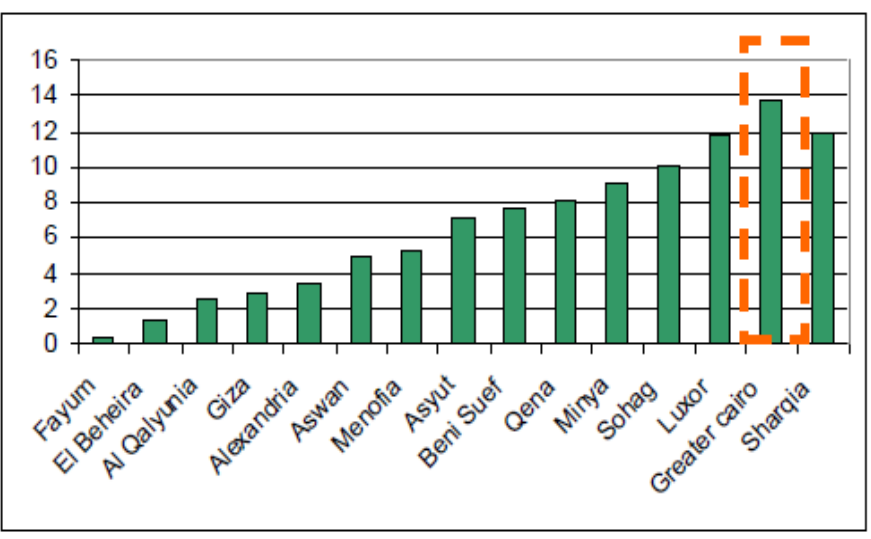

Figure 16. Proportion of implemented low-income housing units by private sector in new cities in each governorate

(Source: CAPMAS, 2019)

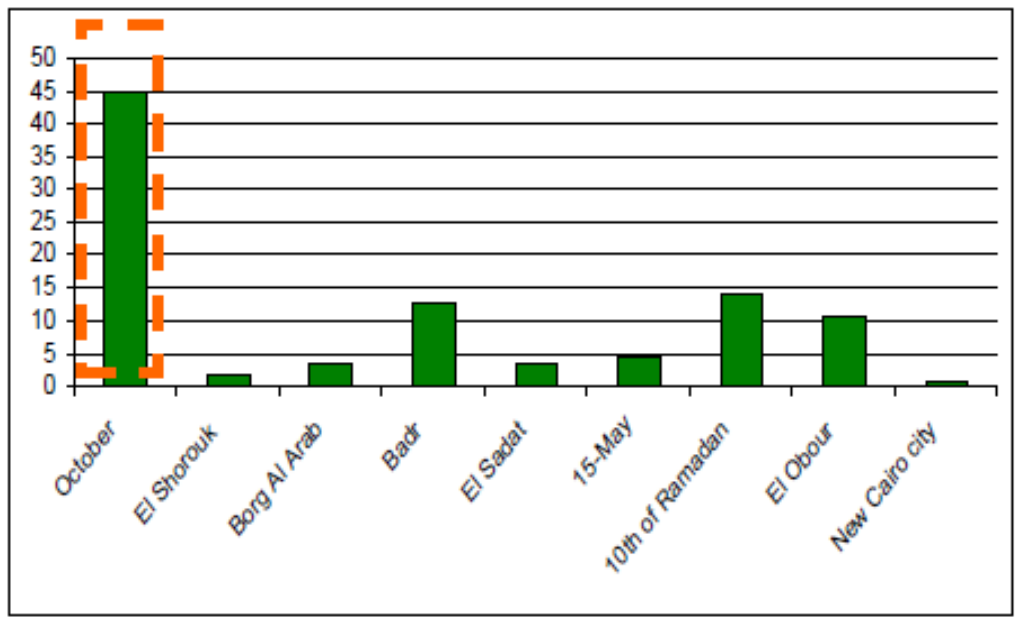

Figure 17. Proportion of implemented low-income housing units by private sector in new cities around greater Cairo

(Source: CAPMAS, 2019)

\section{Private Sector Partnership Projects for Low Income Housing in Six October City}

October City is one of the oldest first generation cities, it is located at $40 \mathrm{~km}$ away from the west of Cairo and it has different levels of housing. Especially low-income housing due to the existence of industrial zone and the increasing of housing demand from workers. Low-income housing projects in October City have developed with its different plans as shown in figure no (18). The initial plan in 1979 showed $38 \%$ of total urban area $\left(350 \mathrm{~km}^{2}\right)$ for low-income housing units, which were built by government funding. These housing units were characterized by high prices compared to income levels that led to not selling most of 


\section{Macrothink}

them and not achieving the target population of this plan (500 thousand people until 2000) (Hegazy and Moustafa, 2013).

The second stage of city development is in 1995 with an area of $\left(480 \mathrm{~km}^{2}\right)$ and the emergence of youth housing and future housing, which were located in the northern and southern extensions of the city. Most of the partnership projects were concentrated in the southern part of the city, where the existence of the low price land and the opportunity to provide investment housing by private sectors in nearby locations (MHUUC, 2008).

The third stage is in 2006 and the emergence of the National Housing Project (Housing Mubarak), the majority of implemented low income housing units by investment companies are located in the southern expansions of Six October City (October Gardens which has an area of about 25 thousand acres). Through allocated land plots to real estate companies for building youth housing units $\left(63 \mathrm{~m}^{2}\right.$ for each unit) such as Rabab, Degla Garden, the Spanish neighborhood at the price of 80 to 150 thousand pounds for each housing unit. In addition to other projects that offer prices from 200 to 250 thousand such as Montazah, Beta Gardens, the Italian neighbourhood and Lotus (MHUUC, 2010).

The fourth phase of Six October development is in 2014 until now and the beginning of social housing project in October gardens, which included thousands of apartments (about 44 thousand of completed housing units, which were implemented by the armed forces and some participants from the private sector. Currently, land is allocated in the south western part of October Gardens to complete the social housing project (MHUUC, 2018).

The Previous Stages show that the most low-income housing projects are concentrated in October Gardens, especially the implemented projects by the private sector. Therefore, this paper selects one of these housing projects (Degla Gardens) to study the offered incentives to private sector in this project and its positive and negative dimensions on the project execution. 


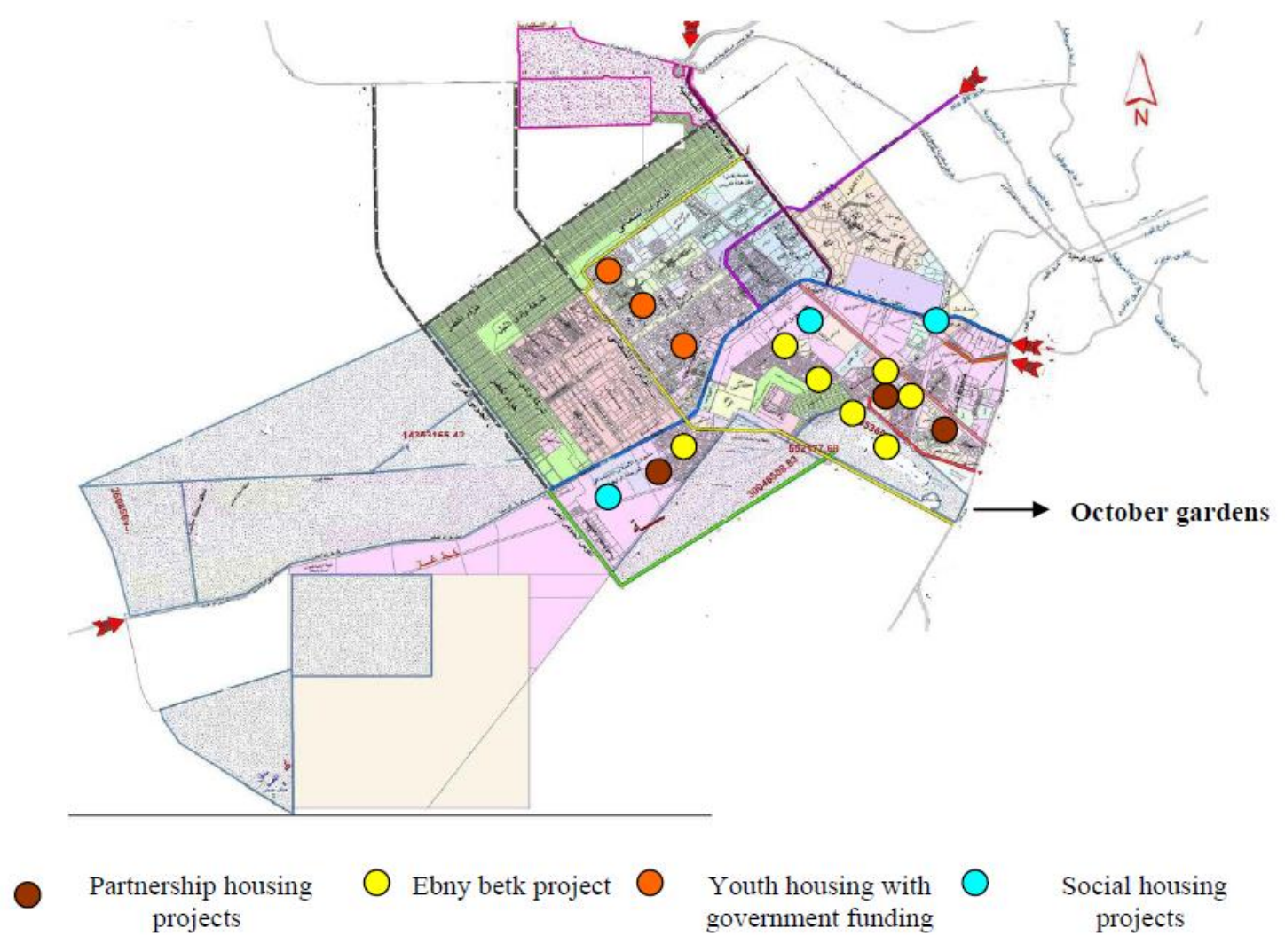

Figure 18. Low-income housing projects in six October City during all stages of development (Source: Author according to MHUUC, 2018; Six October city development Authority, 2019)

\section{Land Use Incentives for the Private Sector in Degla Gardens Project (October Gardens)}

\subsection{Location and Characteristics}

October Gardens is the southern expansions of Six October City; its area reaches 25 thousand feddans and has different levels and types of housing such as (social housing-implemented youth housing by investment companies- free investment housing- Ebny Betak project).

Degla Gardens project is one private sector Partnership projects (National Housing Project) for low-income housing in Six October city (Hegazy and Moustafa, 2013), which is located behind the neighborhood of trees at the entrance of new Zewail university and the Supreme Council of Sports, as shown in figure no (19). 


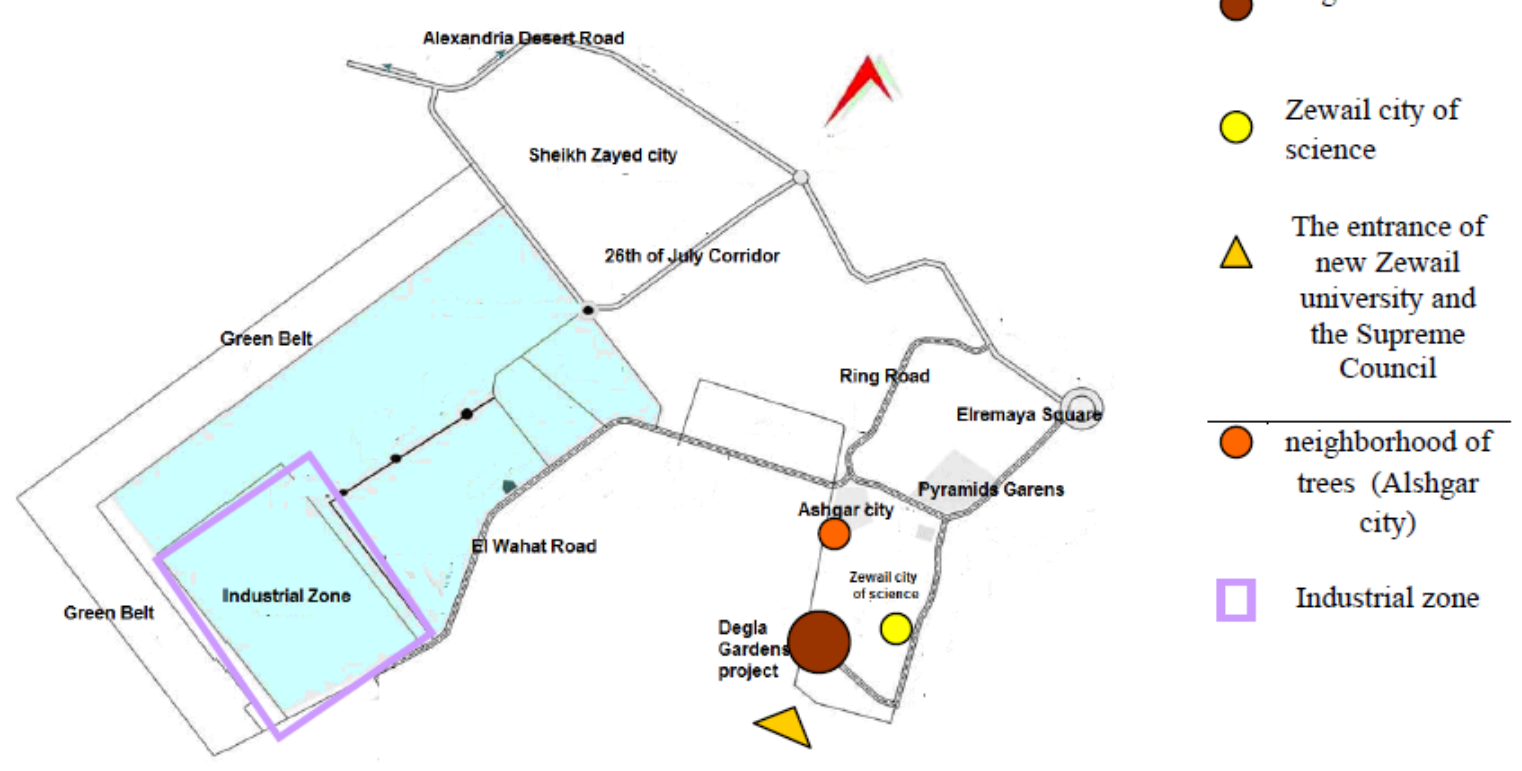

Figure 19.Location of Degla Gardens project in Six October city

(Source: Author according to MHUUC, 2018; Six October city development Authority, 2019)

The State contracted with the Degla Group for Real Estate Investment (Mimar Al Morshedy) by allocating land (land plot no 3 in the October Gardens area) on 26/ 10/ 2006, with an area of about 100 acres to build up an integrated compound housing project (MEC, 2014).

This project started in 2007 after the company received the land on 19/3/2007, to provide about 6840 low-price housing units through four years (2007-2011), with an area of $80 \mathrm{~m}^{2}$ for each unit (figure no 20). Each beneficiary has facilities in buying process such as (paying only 10 thousand pounds for reservation the unit and the rest on installments over 10 years with interest less than 7\%) (MEC, 2014).

The approved plan outlines a set of requirements and characteristics that the company must apply them in this project such as: (MEC, 2014)

- The compound is divided into four stages, each stage 25 acres and all housing have been built on only $20 \%$ of total area. While the rest of area for green areas and services as shown in figure no (21).The first and second phase of this project includes residential buildings (ground floor and five recurring floors), besides garages that are outside the buildings, while the third and fourth phase includes the ground floor for garages under the buildings as shown in figure no (22).

- There are many services in this project such as (mall- restaurants- schools- hospitalnursery- places of worship- social and sports club-playgrounds), which serve only the residents of this project, in addition to available free transportation to the nearest public transport for supporting the movement from housing to work as shown in figures no (23) and (24). 
- Land use plan in Degla Gardens project shows the percentage of each land use as (36.7\% for residential use- $12 \%$ for services- $30.2 \%$ for internal roads and parking$11.84 \%$ for external roads- $9.26 \%$ for green areas and footpaths as shown in figure no $(25)$.

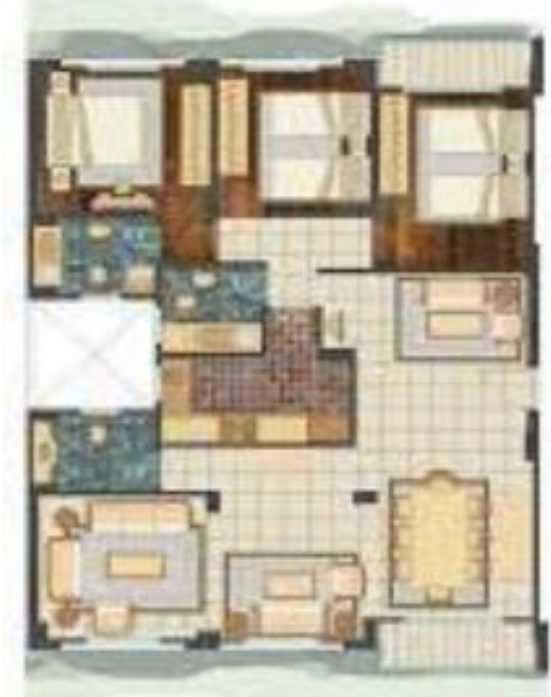

Figure 20. Housing unit in Degla Gardens project

(Source: MEC, 2014)

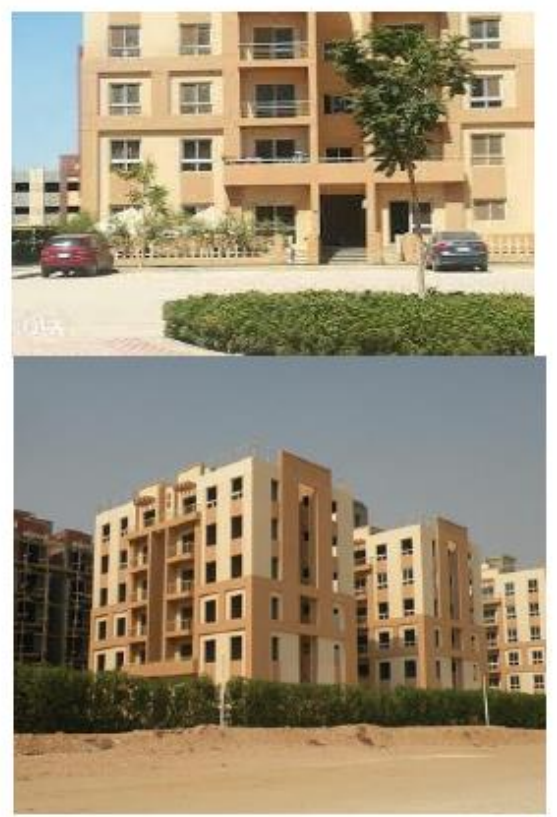

Figure 22. Residential buildings in all stages of project

(Source: MEC, 2014)

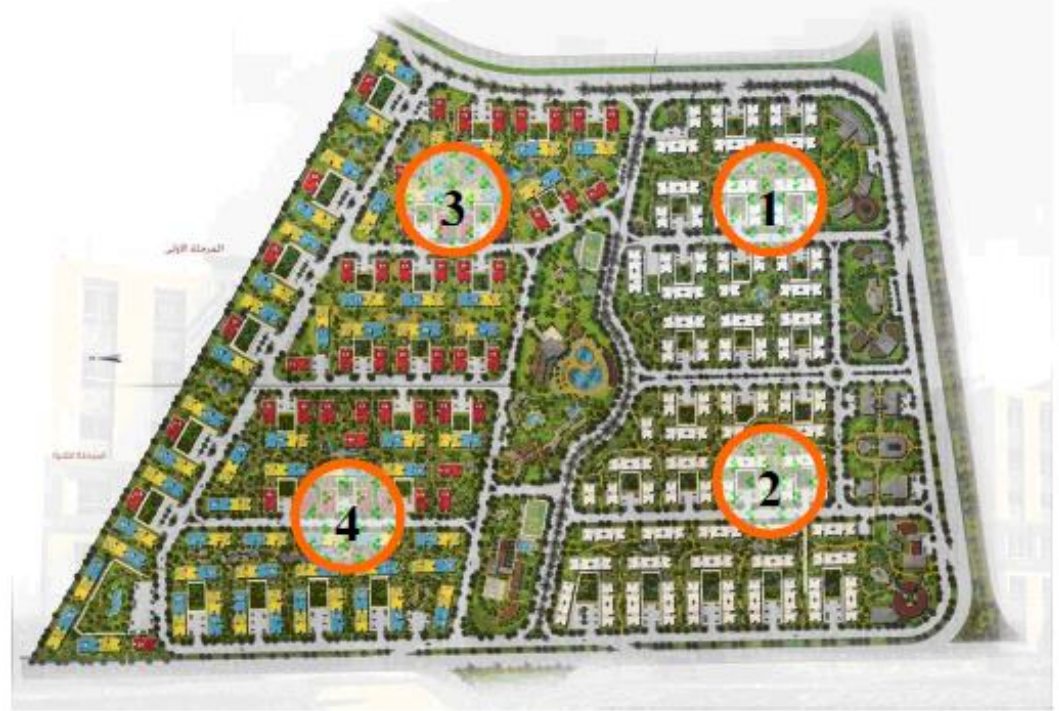

Figure 21. Plan of Degla Gardens project in Six October city (Source: MEC, 2014)

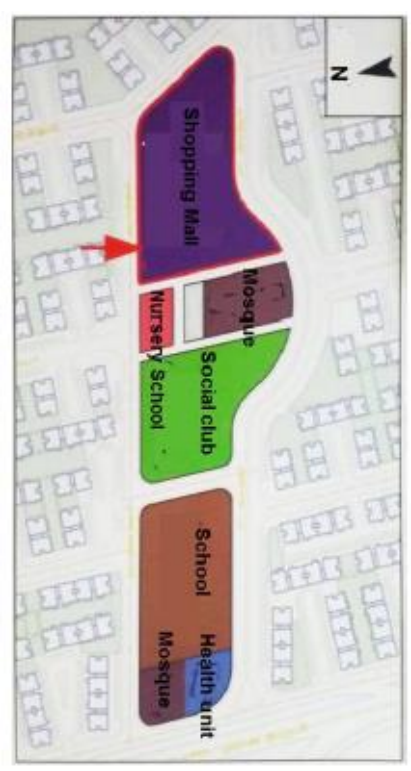

Figure 23. Location of services in the project (Source: MEC, 2014) 

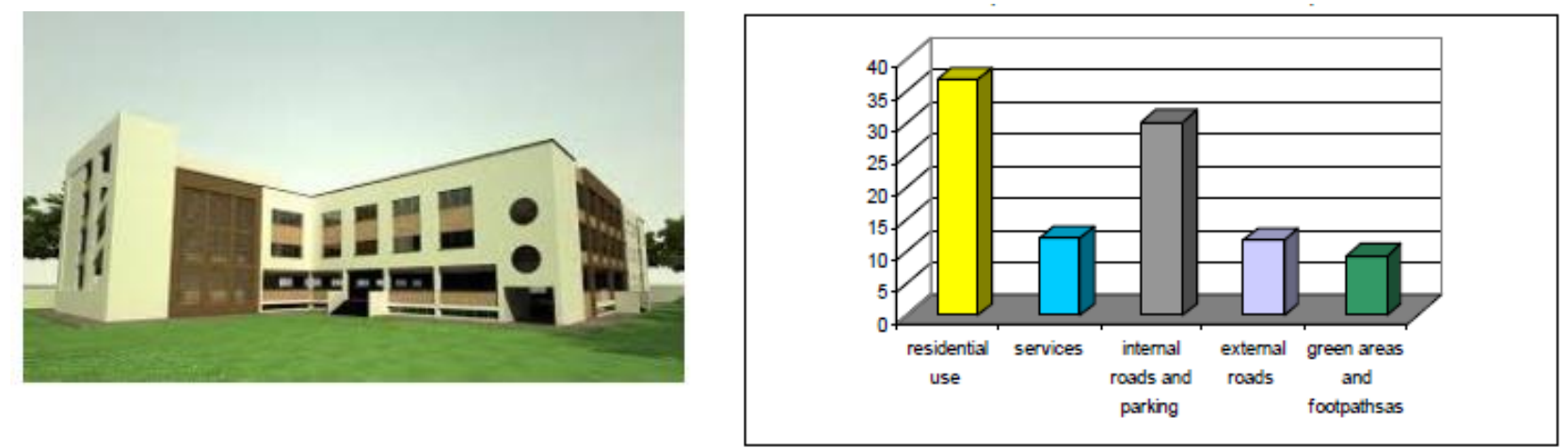

Figure 24. Example of services in the project

Figure 25. Percentage of each land use in the project (Source: Author)

(Source: MEC, 2014)

- Percentage of total buildings area does not exceed $50 \%$ of the total project area.

- The height of the buildings does not exceed 18 meters (6 floors).

- The population density of the project is between 140-240 people / acre.

- The distance between residential buildings isnot less than $10 \mathrm{~m}$.

- Responses of buildings, which are located on main roads (4 meters), while the responses the buildings on the internal roads ( 2 meters).

- Provision parking areas for minimum $70 \%$ of the total number of housing units in the project.

- The company is responsible for designing and executing the internal utilities networks and linking them to the main network, in addition to coordinating the site and paving the internal roads.

- The apartment area must be not less than $63 \mathrm{~m}^{2}$.

- The number of housing units in each floor are (four units).

\subsection{Government Incentives to Mimar Al Morshedy Company during the Project Stages}

Degla Gardens project passed some stages from the contracting to the implementation and follow-up. During these stages, the government provided incentives to Mimar Al Morshedy Company, as shown in the following figure no (26) that illustrates these stages and incentives: 


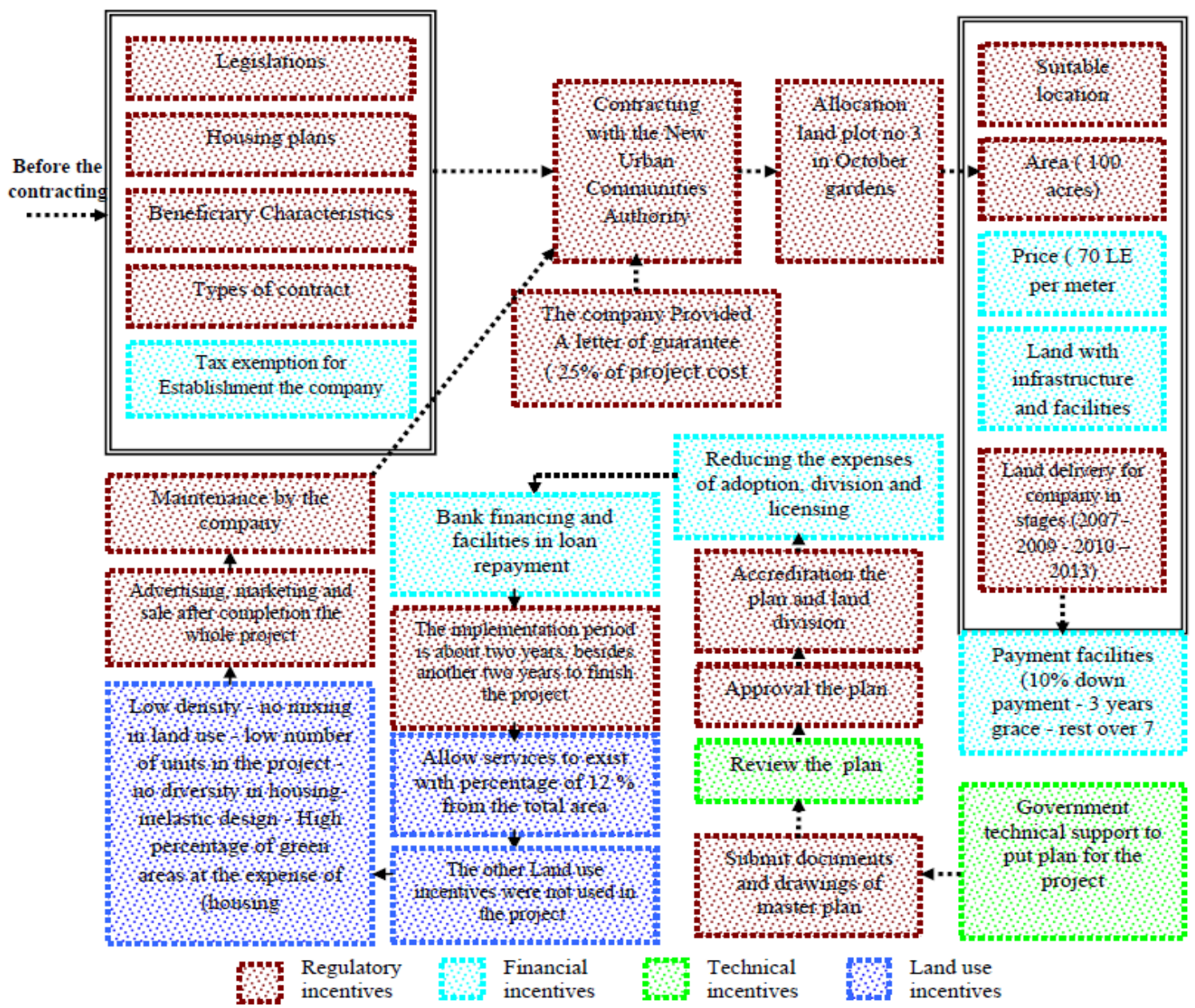

Figure 26. Government incentives to Mimar Al Morshedy company during the project stages

(Source: Author according to the references of MEC, 2014; Chaarawi et al., 2016)

\section{The Main Challenges of Government Incentives in Degla Gardens Project}

The government incentives in Degla Gardens project are characterized by some challenges that must be addressed in introducing new incentives to encourage the private sector in the field of social housing, as shown in table (2).

Table 2. The main challenges of government incentives in Degla Gardens project:

\begin{tabular}{|l|l|}
\hline Kind of incentives & \multicolumn{1}{c|}{ Main challenge } \\
\hline \multirow{3}{*}{ Regulatory incentives } & $\begin{array}{l}\text { Lack of laws that regulate the incentives for the private sector in the field of social } \\
\text { housing, especially land use incentives to benefit from site possibilities in achieving } \\
\text { adequate profitability. } \\
\text { - The government did not identify the price ceiling in the project, which led to selling } \\
\text { housing units at prices (400 thousand pounds that exceed the purchasing ability of the } \\
\text { targeted low-income group). } \\
\text { - The state allocated the project site next to investment areas and away from work areas of }\end{array}$ \\
\hline
\end{tabular}




\begin{tabular}{|c|c|}
\hline & $\begin{array}{l}\text { low-income groups, which did not achieve the objectives of the youth housing project. } \\
\text { - The state allocated small area (100 acres) for the project, which achieved a lower level of } \\
\text { profitability for the company. } \\
\text { - Selling land at a low price ( } 70 \text { pounds per meter), which is less than the economic value } \\
\text { of the site. } \\
\text { - The government agencies delayed in the issuance of licenses and permits (more than a } \\
\text { year from the time of land delivery). } \\
\text { - The government determines a short time for project implementation (two years), which it } \\
\text { is not enough time for the company. } \\
\text { - Non-periodic follow-up of the implementation process by the state to ensure the } \\
\text { achievement of objectives. This led to sell housing units before the implementation has } \\
\text { been completed. } \\
\text {-Non-participation from the government in the marketing and maintenance process for } \\
\text { the project. }\end{array}$ \\
\hline Financial incentives & $\begin{array}{l}\text { - The letter of guarantee ( } 25 \% \text { of total project cost) is not appropriate with the financial } \\
\text { capabilities of the company or other real estate companies. } \\
\text { - High costs of land division and building permits, besides the adoption of development } \\
\text { plan. } \\
\text { - The company bears a high cost to provide internal facilities, which led to not installation } \\
\text { them and the citizens pay an additional cost ( } 4000 \text { pounds) for each unit. } \\
\text { - High interest on loans up to } 10 \% \text {. } \\
\text { - Tax exemption for the establishment of the company only and not for the components of } \\
\text { the project. } \\
\text { - Lack of direct government funding for the project. } \\
\text { - Not provided subsidized construction materials to company for reducing the total cost } \\
\text { of housing project. } \\
\text { - Delay incompletion the project, despite receiving land from the year of } 2007 \text { due to poor } \\
\text { funding and low profitability. } \\
\text { - As a result of the low profitability, the company has sold some services such as the } \\
\text { schools (two schools) and the land of mall to investors for about } 34 \text { thousand pounds per } \\
\text { meter. In addition to exploitation the project in investment way, which is incompatible } \\
\text { with low-income levels of the population. }\end{array}$ \\
\hline Technical incentives & $\begin{array}{l}\text { - Lack of flexibility in planning and design to meet the needs and achieve profitability. } \\
\text { - Weak government technical support during the project preparation and implementation. } \\
\text { - Delay in the review of urban plans, which delays the implementation of the project. }\end{array}$ \\
\hline Land use incentives & $\begin{array}{l}\text { - Land use incentives didn't appear in Degla Gardens project, in which was } \\
\text { characterizedby low building ratio, low housing units. High green areas, low population } \\
\text { density, no diversity in housing types and no mixing in land uses. } \\
\text { - The company resorted to some irregularities, to achieve profitability such as building } \\
\text { commercial activities at the expense of green areas, construction of additional floors, } \\
\text { reduce the area of housing units and reduce allocated area for parking. }\end{array}$ \\
\hline
\end{tabular}

(Source: Author according to the references of Alexbank, 2012; World Bank,2009; World Bank, 2012; MEC, 2014) 


\section{Results and Recommendations}

This paper discusses a new approach (land use incentives), to activate the participation of private sector in social housing projects, which are adopted by many countries such as United States and Germany. On the other side, this kind of incentives is suitable for developing countries that suffer from low government funding and weak financial incentives towards low income housing projects, because it depends on the optimal utilization of land potentials with low cost and high returns, to achieve a balance between the objectives of the state, the profitability of private sector and the needs of the population. The main results of this paper focuses on how to increase the participation of private sector in social rental housing projects through some incentives, which come from the review of some international reports, such as World Bank report in 2014 and 2018, in addition to the results of successful international experiences and the analysis of the case study, as shown in the following groups:

The first group of incentives (in pre-partnership stage), concern with the state's provision of a favorable environment for investment in the field of housing through (formulation laws of investment, planning and design for social housing projects- putting an incentive plan for housing investment- establishing governmental institutions for partnership- identifying suitable contracts- developing a financing framework for housing projects- determining the beneficiaries of the project and their needs- determining profitable and suitable price ceiling for all partners- implementing the principles of successful partnership).

The second group of incentives (in project preparation stage), which are represented in (selecting the appropriate site for social housing projects- granting land for free or at discounted prices- providing land with utilities- tax exemptions on the establishment of the company and the components of the project- putting administrative and organizational facilities for all the procedures of the project- reduction the fees- technical support for the project preparation at specifications appropriate).

The Third group of incentives (in financing stage), in which the state provides financial incentives for supporting the private sector to start the implementation stage, these incentives are (providing direct government funding- soft loans- fixing the interest rate on loans during the period of preparation and implementation).

The fourth group of incentives (in implementation stage),concern with land use incentives in order to achieve the objectives of all project parties and maximize the profitability of the private sector. These incentives are (increasing buildings density- increasing the number of social housing units in the project-mixing in land use- land reusing for some land plotsreducing the area of residential land plot- reducing the area of the housing unit-low area for green areas, roads and parking- diversification in housing types- economics of design and planning- putting detailed requirements for each area in the project- using advanced low cost construction systems and materials- specify a suitabletime for project implementationfollow-up all steps of implementation).

The fifth group of incentives (in follow-up and marketing stage), which are (advertising and marketing- control of the time of sale and leasing- financial support for sale at discounted 
prices - allowing the leasing for a specific period before selling).

This paper also puts a set of recommendations for Degla Gardens project and other low income housing participation projects in new Egyptian cities that need additional incentives, especially land use incentives, which were not applied in Egyptian reality and have an important role in encouraging the real estate companies to contribute in similar future housing projects, these incentives are:

- Positing new laws of land use incentives and developing the current investment laws.

- Setting a price ceiling for the sale of residential units to be appropriate with lowincome levels and the required profitability for the private sector.

- Allocating a suitable land area for real estate companies to achieve the appropriate profitability from housing project.

- Locating the project site in low-price land to be suitable for social housing.

- Reducing the time of obtaining licenses to accelerate the starting of implementation stage.

- Advertising, marketing and maintenance by the state to help the private sector for gaining his profitability in less time.

- Allowing the flexibility in planning and design to cover different needs.

- Providing technical support for all stages of project to implement the project in low cost.

- Increasing the density of buildings (density bonus), to meet the high demand of housing and achieve a higher level of profitability.

- Reducing the area of the housing unit to $60 \mathrm{~m} 2$, besides the area of green areas and roads.

- Subtracting different areas for housing units within the same site.

- Allowing the mixing in land use and the existence of commercial activities in the site which not less than $15 \%$ from total project area for achieving profitability.

- Providing modern construction systems with cheap price.

\section{References}

Abdul-Aziz, A. R., \& Jahn, K. P. S. (2011). Objectives, success and failure factors of housing public-private partnerships in Malaysia. Journal of Habitat Tnt, 35(1), 150-157.

http://dx.doi.org/10.1016/j.habitatint.2010.06.005

Abouelmagd, D., Corijn, E., \& Kesteloot, C. (2013). Housing projects for low-income groups and modes of economic integration: a comparative study in Greater Cairo. The International Journal of Social and Economic Geography. https://doi.org/10.1111/tesg.12026 
Ademiluyi, A. I., \& Raji, B. A. (2008). Public and Private Developers as Agents in Urban Housing. [Online] Available:

http://citeseerx.ist.psu.edu/viewdoc/download?doi=10.1.1.545.7694\&rep=rep1\&type=pdf

Alexbank, (2012). Sectoral Survey: Egypt's Real Estate Industry.

Altus Group. (2013). Government Charges and Fees on New Homes in The Greater Toronto Area. BILD Toronto. [Online] Available:

http://www.bildgta.ca/BILD/uploadedFiles/Government_Relations/2013/REVISED\%20Gove rnment\%20Charges\%20in\%20the\%20GTA\%20-\%20July\%2023.pdf

Aribigbola, A. (2008). Housing policy formulation in developing countries: evidence of programme implementation from Akure, Ondo state, Nigeria. Journal of Human Ecol, 23(2), 125-134. https://doi.org/10.1080/09709274.2008.11906063

Burda, C. (2013). Priced Out: Understanding the factors affecting home prices in the GTA. Royal Bank of Canada \& Pembina Institute. [Online] Available:

http://www.rbc.com/newsroom/pdf/Priced-Out-1202-2013.pdf

Buttiiner, L. (2006). Achieving public sector outcomes with private sector partners- a New Zealand perpective. Journal of Govern. Audit, 33(4), 22-25.

CAPMAS, Census for Population and Housing and Establishments 1996 and 2006. final results. [Online] Available: www.capmas.gov.eg/

CAPMAS, (2018). Study of Current and Future Housing Needs in Egypt (2007-2022).

CAPMAS, (2019). Census for Population and Housing and Establishments 2019. [Online] Available: www.capmas.gov.eg/

Cartlidge, D. (2006). Public- private partnership in construction. Oxon: Taylor and Francis. https://doi.org/10.4324/9780203018835

Chaarawi, Z., Khalifa, M., Maarouf, D., \& Abdellatif, M. (2016). Evaluation of Stakeholders realation in housing provision process in Egypt : Case study of $6^{\text {th }}$ October city. Journal of procedia Environmental Science, 34, 618-640. https://doi.org/10.1016/j.proenv.2016.04.054

Chen, J. (2010). On How to Deal with Vacant Housing in China. Exploration and Free Views, $10,57-60$.

City of Vancouver. (2012). Results of Short Term Incentives for Rental (STIR) Program. Presentation to Vancouver City Council, Vancouver Planning and Development Services. [Online] Available:http://vancouver.ca/files/cov/stir-presentation.pdf

City of Vancouver. (2014). Creating New Market Rental Housing. [Online] Available: http://vancouver.ca/people-programs/creating-newmarket-rental-housing.aspx

City of North Vancouver. (2019). Density Bonusing. [Online] Available: http://www.cnv.org/city-services/planning-and-policies/land-use/density-bonusing CODI (Cooperative Organizations Development Institute). (2009). Annual Report. Bangkok, 
Thailand.

Density Bonus plan of North Park. (2016). [Online] Available: https://uh2050.wordpress.com/category/density-bonus-plan-2/

Egyptian Financial Supervisory Authority (EFSA). Report for the Second Quarter of 2014.

ElBoghdady, D. (2011). Affordable Rental Housing Scarce in U.S., Study Finds. Washington Post. [Online] Available:

http://www.washingtonpost.com/business/economy/affordable-rentalhousing-scarce-inus-stud y-finds/2011/04/25/AFcBjilE_story.html

El-Demery, I. M. (2002). Towards A Participatory Loan-Supported housing Scheme Helwan New Community,Egypt. Journal of cities, 19(6), 401-408.

https://doi.org/10.1016/S0264-2751(02)00070-7

Hegazy, I. R., \& Moustafa, W. S. (2013). Toward revitalization of new towns in Egypt case study: Sixth of October. International Journal of Sustainable Built Environment, 2, 10-18. https://doi.org/10.1016/j.ijsbe.2013.07.002

Horowitz, M. (1996). Innovative Financing of Home Efficient Improvement. American Council for an energy efficiency economy, Energy Policy, 2.

Kemp, P. A., \& Stefan K. (2010). Contrasting Varieties of Private Renting: England and Germany. International Journal of Housing Policy, 10(4), 379-98.

https://doi.org/10.1080/14616718.2010.526401

Kofner, S. (2009). The Framework of the Private Rental Housing Sector in Germany. Paper presented at the ENHR Working Group on Private Rented Sector Workshop, York, U.K., April 27-28.

Kolsteren, A. (2012). Affordable Housing In Toronto: Legislative And Regulatory Tools For Municipal LED Development. Ryerson University Theses and Dissertations, Paper 1547, [Online] Available:

https://digital.library.ryerson.ca/islandora/object/RULA:1972/datastream/OBJ/download/Affo rdable_Housing_In_Toronto__Legislative_And_Regulatory_Tools_For_Municipal_LED_De velopment.pdf

Law No.107. (1976). Financing economic housing projects, Egypt.

Law No.59. (1979). New Urban Communities, Egypt.

Law No.8. (1997). Investment law, Egypt.

Law No.119. (2008). Unified Building, Egypt. https://doi.org/10.1163/22112987-91000210

Law No.67. (2010). Public- private partnership, Egypt.

Law No.55. (2014). Real Estate Finance, Egypt.

Law No.72. (2017). Investment law, Egypt. 
Law No. 93. (2018). Social Housing and Mortgage Support, Egypt.

Lewchuk, S. (2013). Affordable housing in Canada: an economically sound investment. Citizens for Public Justice. [Online] Available:

http://www.cpj.ca/content/affordable-housing-canada-economically-soundinvestment

Master planning for rare, north-facing riverfront land. (2019). [Online] Available:

http://deickerichards.com.au/project/bulimba-barracks-master-plan/

Memaar Elmorshidy company, (2014). Degal Gardens project. [Online] Available:

www.memaarelmorshidy.com

Minnesota Department of Natural Resources. (2001). Conserving Natural Resources through Density Bonuses. [Online] Available:

https://files.dnr.state.mn.us/assistance/nrplanning/community/nrchecklists/densitybonus.pdf

Ministry of Finance, PPP Central Unit, “Wastewater Sector,” April 2015.

Ministry of Housing, Utilities and Urban Communities (MHUUC). (2008). Conceptual Master Plan and detailed master plan for the study area of Six October city, Egypt.

Ministry of Housing, Utilities and Urban Communities (MHUUC). (2010). The Gerneral Strategic Planning for Six October and Sheikh Zaied as one city, Egypt.

Ministry of Housing, Utilities and Urban Communities (MHUUC). (2016). Social housing project. [Online] Available:

http://newcities.gov.eg/about/Projects/Housing_projects/SocialHousing/default.aspx

Ministry of Housing, Utilities and Urban Communities (MHUUC). (2018). The Gerneral Strategic Planning for Six October, Sheikh Zaied as one city and October gardens, Egypt.

Ministry of Housing and New Urban Communities Perera, R. (2005). Rental Housing of the Low-Income Groups in Bangkok Metropolitan Area: A Study of the Existing Typology of Housing and Their Environmental Conditions. Bangkok,National Housing Authority of Thailand.

Prefabricated Social Housing. (2019). [Online] Available:

http://www.atelieraitken.org/perfabicated-homes

Rodrigue, J. P. (2017). The Geography of Transport Systems, New York. [Online] Available: http://transportgeography.org/?page-id=4956

Scherlowski, D. (1999). Municipal Regulatory Initiatives: Providing for Affordable Housing, Richard Drdla Associates Inc.

Sengupta, U. (2006). Government intervention and public-private partnerships in housing delivery in Kolkata. Journal of Habitat Int, 30(3), 448-461.

http://dx.doi.org/10.1016/j.habitatint.2004.12.002

Six October city development Authority, [Online] Available: www.6october.gov.eg 


\section{Macrothink}

Environmental Management and Sustainable Development

ISSN 2164-7682

2020, Vol. 9, No. 1

UN-HABITAT (United Nations Human Settlements Programme). (2003). Rental Housing:An Essential Option for the Urban Poor in Developing Countries, Nairobi.

UN-Habitat. (2012). Sustainable Housing for Sustainable Cities: A Policy Framework for Developing Countries, Nairobi.

USAID and Ministry of Investment, Housing Demand Study for the Arab Republic of Egypt, TAPR II, June 2006.

USAID/TAPRII, Review of Egyptian Subsidized Housing Programs and Lessons Learned.

Verde land \& Water Planning Toolbox. (2016). Density Bouns. [Online] Available:

https://verderiver.org/density-bonus/

World Bank. (2008). Arab Republic of Egypt: Next Step Recommendations for Affordable Housing Policy and the National Housing Program.

World Bank. (2009). Egypt Affordable Mortgage Finance Program Development Policy Loan, the World Bank. Washington, D.C.

World Bank. (2012). Implementation Completion and Results Report for a Mortgage Finance Project, No. ICR2014.

World Bank. (2014a). Arab Republic of Egypt, Inclusive Housing Finance Program Program-For-Results Information Document (PID), Concept Stage, 8 August, 2014.

World Bank. (2014b). Rental housing- lessons from interntional Experience and policies for Emerging Markert, the World Bank. Washington, D.C.

Zhang, X. (2005). Criteria for selecting the private-sector partner in public-private partnerships. Journal of Construct. Eng. Manage, 13(6), 631-644.

https://doi.org/10.1061/(ASCE)0733-9364(2005)131:6(631)

\section{Copyright Disclaimer}

Copyright for this article is retained by the author(s), with first publication rights granted to the journal.

This is an open-access article distributed under the terms and conditions of the Creative Commons Attribution license (http://creativecommons.org/licenses/by/3.0/). 